\title{
Are Tenured Judges Insulated from Political Pressure?*
}

\author{
Jordi Blanes i Vidal ${ }^{\dagger} \quad$ Clare Leaver ${ }^{\ddagger}$
}

October 25, 2010

\begin{abstract}
Tenured public officials such as judges are often thought to be insulated from political pressure and, as a result, indifferent to the concerns of the electorate. We investigate this proposition empirically using data on promotion decisions taken by senior English judges between 1985 and 2005. Throughout this period the popular view was one of ill-disciplined elitism: senior judges were alleged to be favouring candidates from elite backgrounds over their equally capable nonelite counterparts. We find evidence in support of this view to be surprisingly weak; most of the unconditional difference in promotion prospects between the two groups can simply be explained by differences in promotion-relevant characteristics. We then exploit an unexpected proposal to remove control over promotions from the judiciary and find that judges' behaviour dramatically changed. When faced by the prospect of losing autonomy, senior judges began to favour non-elite candidates, as well as candidates who were unconnected to members of the promotion committee.
\end{abstract}

${ }^{*}$ We thank Oriana Bandiera, Pablo Casas-Arce, Daniel Ferreira, Paul Klemperer, Ignacio Palacios-Huerta, Howard Smith, Kathy Spier, John Vickers, various seminar audiences and, in particular, the Editor and two anonymous referees for their helpful comments and suggestions. We are also grateful to Baroness Hale, Kate Malleson, Lord Justice Maurice Kay, the Commission for Judicial Appointments, Her Majesty's Courts Service and the Ministry of Justice for many useful conversations. All errors are our own.

${ }^{\dagger}$ Corresponding Author. Lecturer, Managerial Economics and Strategy Group, London School of Economics. Houghton Street, London WC2A 2AE, United Kingdom, +44 (0) 2079 556041; Email: j.blanes-i-vidal@lse.ac.uk.

${ }^{\ddagger}$ Lecturer, Department of Economics, University of Oxford. Manor Road, Oxford OX1 3UQ, United Kingdom, +44 (0) 1865 271952; Email: clare.leaver@economics.ox.ac.uk 


\section{Introduction}

The wisdom of subjecting public officials to democratic accountability continues to stimulate debate. The first generation of agency-theoretic models (Barro 1973, Ferejohn 1986) highlighted that elections could 'discipline' bad types. More recently, it has been argued that electoral incentives could result in 'pandering' - excessive catering to public opinion- by good types (Canes-Wrones et al 2001). This tension, coupled with evidence on the association between political constitutions and economic performance (Persson and Tabellini 2003), has renewed interest in the normative study of decision-making powers, i.e. who should get to decide what?

The typical approach within this field is to conflate unaccountability with permanent (i.e. tenured) employment. Maskin and Tirole (2004), for instance, contrast an official who must stand for re-election - a "politician" - with a tenured official who, as a result of his job security, pays no heed to beliefs held by voters - a "judge" - (see also Eggertsson and Le Borgne 2006 and Schultz 2008). While useful as a modelling shortcut, caution is needed in drawing prescriptions for policy, especially those based on an assumption that tenured officials attach no weight to voters', or their elected representatives', preferences. Given the inalienable power of the Executive, decisions can be removed from tenured public officials even if employment cannot. If tenured public officials are keen to retain their decision-making power, then it may be better to think of them as open to influence rather than as insulated from political pressure. Indeed, history lends some support to this idea. According to the traditional view of the famous 'switch in time that saved nine', US Supreme Court Justice Owen J. Roberts changed his position on New Deal legislation to prevent President Roosevelt from increasing the size of the Supreme Court, a move that would have diluted the power of the nine incumbent Supreme Court judges.

As with predictions from political agency models, empirical evidence in this area is sorely lacking (Besley 2006), and even the traditional interpretation of Justice Roberts' change of heart has been questioned (Hulsebosch 1990, Shea 2005). The objective of this paper is to fill this gap. Using a unique new data set, we study the behaviour of "judges" and find that (at least some) aspects of their decision-making can be influenced by political pressure.

Purposely, we focus on a scenario where in principle it seems likely that tenured public officials are insulated from political pressure, namely the senior English judiciary. Senior judges are the preeminent example of public officials with lifetime tenure, which is clearly a minimum 
requirement for our purposes. We focus on the English case for two reasons. ${ }^{1}$ First, in England, judicial resignations are extremely rare. ${ }^{2}$ Since senior judges are already at the top of the hierarchy, career concerns are unlikely to be an important force. ${ }^{3}$ Second, the English judiciary is highly unrepresentative of the population it serves and commonly criticised for being elitist. For instance, a recent study by an educational pressure group lamented the fact that over $50 \%$ of senior English judges had attended boarding schools (the most prestigious private schools) compared to just $1 \%$ of the general population (Sutton Trust 2005). Such a skewed social background makes it highly likely that judicial policy preferences will differ to those of the average citizen. Consequently, if senior judges are insulated from political pressure, then this should translate into undisciplined decisions divergent from those preferred by the median voter and their elected officials.

In addition to hearing cases, an important function performed by senior English judges has been to select future colleagues. ${ }^{4}$ These appointment decisions - specifically, the decisions by promotion committees formed to fill vacancies in the Court of Appeal between 1985 and 2005- are the basis of our study. Again, this focus is easy to motivate. An obvious benefit is that it is easy to define a given promotion committee's action space: picking a candidate from the 100 or so judges serving in the High Court for the (exogenously determined) vacancy in the Court of Appeal. More importantly, the public perception was one of elitism; an observation that was widely cited by the Labour Government when stating the case for recent reforms. Lastly, the existence of official criteria makes it reasonably straightforward to categorise decisions. Selection of the candidate that most closely meets the official criteria can be interpreted as either a congruent or disciplined decision. A lack of discipline would instead correspond to favouring elite candidates or, to use the words of a former law lord, selecting "chaps like ourselves".

Having described the relevant legal institutions and explained how candidates are expected to meet the official criteria, in Section 3 we ask whether there is any evidence that senior judges did

\footnotetext{
${ }^{1}$ We use English to refer to England and Wales. Scotland and Northern Ireland have separate legal systems.

${ }^{2}$ The resignation of a High Court judge in June 2005 was the first in 35 years and "risked the disapproval of the legal establishment by breaking the unwritten convention that the bench is a life sentence ended only by retirement or death", The Guardian, June 232005.

${ }^{3}$ This observation distinguishes our "judges" from the "bureaucrats" studied by Alesina and Tabellini (2007).

${ }^{4}$ While senior judges play no role in selecting judges in the US, this is a task performed by judges in many jurisdictions. Thomas (1997) documents that judges sit on appointment committees in most Western European countries. A substantial proportion of these appointing judges are nominated by the judiciary itself, e.g. of the 33 members of Consiglio superiore della magistratura (the institution responsible for judicial appointments in Italy), 20 are directly chosen by the judiciary. For a more detailed international comparison of procedures see Appendix A.
} 
favour elite candidates. We start by presenting the raw data: the promotion prospects of the 275 judges serving in the High Court between 1985 and 2005. Consistent with the popular stereotype, elite judges were substantially more likely to be promoted, even after adjusting for censoring.

We explore whether this was due to favouritism in a number of different ways. First, using a discrete choice model of promotion committee decision making, we ask whether the elite differential: (i) is unresponsive to controlling for officially relevant candidate endowments; (ii) falls when controlling for endowments argued to be the micro-foundation for favouritism by political and legal commentators (personal ties to members of the promotion committee such as attending the same school or practicing from the same chambers); and/or (iii) is lower for 'high stakes' vacancies generated by promotions to the House of Lords. Then, using a model of intellectual influence based on Palacios-Huerta and Volij (2004), we ask (iv) whether promoted non-elite judges outperformed promoted elite judges once in the Court of Appeal. Under the favouritism interpretation, the answers to these questions should be positive. Our answers are however consistently negative. Taken individually, each piece of empirical evidence is not sufficient to establish the existence of disciplined or congruent decisions. But taken together, the weight of evidence makes the notion of favouritism of elites seem unlikely. Instead, the raw differential appears due to the fact that elite candidates were better endowed with promotion-relevant characteristics.

We then proceed to examine more directly the hypothesis that judicial behaviour is influenced by political pressure by identifying a time period in which the source of accountability discussed the threat to remove decision-making power- dramatically increased. The period we use is 20032005. In June 2003, the British Prime Minister took the legal world by surprise by announcing that responsibility for judicial appointments was to be transferred to a new commission that would act in conjunction with an elected cabinet minister. This announcement raised the possibility that senior judges would lose de facto control of promotions to lay commissioners and politicians. Critically for our purposes, the details of the reform -including the amount of power that judges would hold in the future- were not settled until March 2005. Between these dates, the senior judiciary openly lobbied the Government for more power under the new system, while still promoting judges under the old one. Clearly, these decisions ( $18 \%$ of our sample) were made under the threat of reform, with obvious returns to minimising perceptions of favouritism.

In Section 4 we disaggregate our results either side of this unexpected shock to the system. Our findings are consistent with the view that there was an increase in accountability and that this led to a desire to appear disciplined, even to the extent of possibly favouring non-elite candidates. 
The partial effect of elite status in our discrete choice model was significantly smaller (in fact negative), and the (weakly negative) association between personal ties and promotion prospects significantly stronger, after the announcement.

Our empirical analysis is related to the literature on labour economics examining the existence of racial and gender discrimination (see for instance Altonji and Blank 1999). The most convincing studies in this field make use of randomised experiments to alter perceptions of race (Bertrand and Mullainathan 2004) or the matching between evaluators and candidates (Bagues and EsteveVolart 2007, Price and Wolfers 2007). Since randomised experiments are not feasible in our setting, we employ several different strategies and then draw conclusions on the basis of the weight of (observational) evidence.

A growing body of research supports the notion that appointed and elected officials take different decisions. Besley and Coate (2003), for instance, find that elected regulators are more pro-consumer than appointed regulators. In a judicial context, Lim (2008) finds that elected judges in the state of Kansas are significantly more responsive to the political orientation of their district than appointed judges. Studying the same US state, Gordon and Huber (2007) show that elected judges are harsher in sentencing than appointed judges, especially before elections. Iaryczower et al (2010) use a structural model of committee decision-making to argue that appointed judges make fewer mistakes than their elected counterparts (see also Choi et al 2010). Our paper differs from this literature because we focus exclusively on appointed judges and, moreover, we explore how their behaviour is affected by the possibility of losing decision-making power.

Our findings suggest that insulation from the electorate is never perfect, even for tenured public officials appointed on permanent contracts. This observation has implications for both theory and policy. On the theoretical front, to the extent that our findings carry over to material policy decisions, it casts doubt on the wisdom of equating tenure (permanent contracts) with unaccountability. Instead it may be more fruitful to regard tenured officials as separated from the electorate by a middle layer of elected officials that both shields them and threatens to remove their powers. This latter source of accountability does, however, provide empirical support for the emerging theoretical consensus that government employees are motivated by policy outcomes. In fact, we highlight a new, and as yet unmodelled, dynamic trade off: tenured public officials appear to value autonomy and may take distortionary steps to protect it.

Turning to policy, our findings suggest that dissatisfaction with the observed behaviour of public officials should not necessarily be taken as evidence of lack of accountability and hence a need 
for reform. With the decisions taken by senior English judges prior to 2005 apparently driven by 'pre-market' factors rather than ill-disciplined elitism, recent constitutional reforms seem unlikely to ease public concerns. As we argue in the Conclusion, this observation already appears to have been borne out, with widespread disappointment following the introduction of the new judicial appointments commission in England and Wales. Indeed, one might go further and argue that the English public would have been better served by reforms that protected, rather than weakened, the autonomy of their senior judiciary.

\section{Background and Data}

\subsection{Legal Institutions}

Figure 1 illustrates the three courts relevant to our study. The Crown Court is primarily a criminal court, and cases are heard by Circuit judges. The High Court has three divisions. The Queen's Bench handles a mixture of civil and criminal cases and judicial reviews. The two other divisions handle cases in family and chancery matters. High Court judges are assigned to a division upon appointment, typically reflecting their prior legal specialism (e.g. public law specialists to the Queen's Bench, tax specialists to the Chancery Division). Most cases are heard by a single judge. The Court of Appeal has two divisions and judges are not assigned to a particular division upon appointment. The Criminal Division handles criminal appeals from the Crown Court, and the Civil Division civil appeals. Most cases are heard by three judges. It is common for High Court judges to sit in the Criminal Division but not in the Civil Division.

During our sample period, the vast majority of High Court appointments were from the Bar rather than the Circuit bench. In contrast, all Court of Appeal appointments were promotions from the High Court. For what follows, it is important to identify three features of this promotions process: how vacancies arise, the composition of the selection committee, and the official criteria for promotion. The first issue is clear cut. A vacancy arises if and only if a Court of Appeal judge exits or Parliament creates a new post. During our sample period, there were 85 vacancies. Of these, 69 arose due to exits (38 retirements, 1 death and 30 promotions to the House of Lords), while 16 were new posts.

Formal responsibility for these promotion decisions lay with the Lord Chancellor (and ultimately with the Queen of England), a cabinet minister rather than a serving judge. In practice, however, the system was closer to self-governance, with 'judges choosing judges'. When a vacancy 
arose the Lord Chancellor reviewed candidates at a meeting with the Heads of Division and a few other senior judges (Peach Report, 1999). Comments by the Judges' Council (the judiciary's representative body) suggest that serving judges played a crucial role at these meetings:

"the judiciary as a whole, and the Heads of Division in particular, are deeply involved in the process. The Lord Chancellor's decisions have, in practice, drawn heavily on the advice that the judiciary has been able to give. Indeed, in respect of senior judicial appointments made or recommended by the last two Lord Chancellors, it is believed that no appointment has been made to which the Heads of Division raised objection", Judges' Council (2003, paragraph 71).

In light of this evidence, we take the composition of a promotion committee formed to fill a given vacancy to be the incumbent Heads of Division and Lord Chancellor. The decision problem faced by such a committee was to select one of the serving High Court judges for promotion.

Throughout our sample period the choices made by these committees were subject to intense criticism, with claims that judges with an elite background were being given undue preference. To explore allegations of favouritism we must obviously identify the criteria upon which promotion decisions should be based. The official guiding principle has always been 'merit' (DCA 2005). The Judges' Council usefully elucidates how this principle has been applied in practice:

"There is the general quality of the candidate, as a judge of demonstrated outstanding ability, and there is the requirement that the candidate should also have expert knowledge of the specialist area of the law which will be required to meet the needs of the Court of Appeal. The Court of Appeal judges are also potential candidates for membership of the House of Lords (...) The scope for further promotion must also be taken into consideration when determining at what stage of their judicial career particular candidates should be promoted." Judges' Council (2003, paragraphs 98-99).

Further clarification follows:

'The best testimony as to whether judges have the necessary qualities for promotion to the Court of Appeal is their track record since being appointed as judges. This, to a judicial colleague, will be demonstrated by the quality of their judgements. Those judgements will have been carefully studied on appeals by a candidate's senior colleagues.' Judges' Council (2003, paragraph 99). 
We interpret the above as saying that age, experience, the match between a candidate's legal specialism and the needs of the Court of Appeal, and ability as evidenced by good judgements are the key promotion criteria. Our data collection exercise is tailored accordingly. Using the case law provider Westlaw, we follow each published case heard by the 275 High Court judges serving during our sample period (a total of over 28,000 cases) and then record the legal subject and all subsequent appeals and citations. Then, at the date of each promotion decision, we construct measures of quality (reversals and affirmations by members of the promotion committee), legal specialism (High Court division and legal subject of past cases), age and experience. To capture the 'needs of the Court of Appeal', we also record the High Court division and destination (retirement or promotion) of the exiting Court of Appeal judge, if any.

\subsection{International Context}

Existing mechanisms to appoint and promote senior judges vary greatly around the world. In Appendix A we provide an overview of the different institutions and place the English system within this wider context. A point worth emphasizing here is that, as in England, senior judges enjoy a significant amount of influence in the appointment systems of many other countries. In some countries, such as India, they hold the formal responsibility over the final decision (Neuborne 2003). In others, such as Japan and the Netherlands, senior judges have the power to propose a candidate, with the unwritten convention that the executive will always accept this proposal (O'Brien 2006, De Groot-Van Leeuwen 2006). Lastly, in countries such as Israel, the judiciary's influence arises from their control of the judicial appointments commission. Indeed, in an interesting parallel with the English experience, this influence has recently been threatened by the Israeli parliament (the Knesset), apparently in retaliation for the Supreme Court ruling several pieces of legislation as unconstitutional. $^{5}$ Thus, while the precise details of the English system are unique, our study of the promotion decisions taken by senior English judiciary should have important lessons for other systems where judges hold a significant amount of power. We return to this point in Section 5 .

\footnotetext{
${ }^{5}$ In 2000 the Israeli Knesset reviewed the procedure for selecting judges. While this review ended up praising the existing system, several leading politicians expressed their desire to reduce the number of judicial commissioners from 3 to 2, in order to dilute their power (Salzberger 2006). Soon after in 2003 a motion in the Knesset was proposed to establish a Constitutional Court that would bypass the Supreme Court, effectively stripping it of the power of subjecting legislation to constitutional review. This was widely regarded as retaliation for the judicial activism displayed by the Supreme Court and was only narrowly defeated.
} 


\section{$2.3 \quad$ Elite Status}

Since our objective is to explore whether tenured judges are influenced by political pressure, we wish to use a measure of elite status that captures how the term 'elitism' was used in the public debate surrounding judicial appointments. In this section, we describe the popular notions of elitism that prevailed during our sample period, and then how these observations shape the construction of our key independent variables.

The characteristic most commonly associated with membership of the English elite is attendance at a prestigious private school. Consistent with this interpretation, when pointing to elitism, politicians and interest groups typically highlighted the narrow educational background of the senior judiciary; ${ }^{6}$ a claim that is evident in our data, with $213(77 \%)$ of the 275 judges serving in the High Court between 1985 and 2005 attending a fee-paying school.

If lay commentators tended to emphasise where judges were educated, then legal experts tended to focus on where judges worked prior to appointment. The typical employment history of a High Court judge is several decades private practice as a barrister and a short-period serving as a part-time judge. This is true for $236(86 \%)$ of the judges in our sample, with just 38 promotions from the Circuit bench and one appointment from private practice as a solicitor. Such uniformity in the type of employment history masks important differences, however. Indeed it is where, not whether, an individual practices as a barrister that is often thought to be the key to future success. Malleson (2000), for instance, reports a senior judge describing the relationship between membership of a top-ranking chambers and judicial office as a "golden road".

Motivated by these observations, we construct our key independent variables using both educational and occupational information. Specifically, we first identify the judges who were promoted to the High Court from the Circuit Bench. Next, we subdivide the remaining state-educated judges into two groups: those who attended an Oxbridge university and then practiced from a top-ranking chambers, and those who followed other routes to the bench. ${ }^{7}$ We define a set of chambers to be top-ranking if it is included in The Lawyer Top 30 ranking (see Table A1). Repeating this last step for the remaining privately educated judges, we have five categories: (i) Private-Oxbridge-Top-

\footnotetext{
${ }^{6}$ The Sutton Trust's study cited in the Introduction, and a subsequent report on the background of journalists, prompted The Independent to run a frontpage article under the headline "Stranglehold" on July 152006. See also the evidence given to the House of Commons Home Affairs Select Committee by a Labour MP in 1996: "we are concerned that an astonishing $80 \%$ of the senior judiciary were privately educated".

${ }^{7}$ As one might expect given the "traditional nature of the Bar" (Malleson 2000), almost all judges appointed from a top-ranking chambers attended Oxford or Cambridge University (commonly abbreviated to Oxbridge).
} 
Ranking, (ii) Private-Other, (iii) State-Oxbridge-Top-Ranking, (iv) State-Other, and (v) Circuit. To simplify the exposition, we present our unconditional and baseline regression results using a binary 'Elite' variable that is coded to 1 for the 195 judges in the first three categories (hereafter referred to as the Elite), and 0 for the 80 judges in the last two categories (the Non-Elite). Then, to quantify the relative importance of education and occupation, we perform robustness checks using a set of dummies for the five separate 'Route to the Bench' categories.

Before comparing promotion prospects across groups, we briefly pause to ask why Elite judges might be favored. In this respect, the leading explanation for the existence of favouritism is that the (overwhelmingly Elite) committee members might have a tendency to look for candidates who share their narrowly-defined background. ${ }^{8}$ In fact, a former law lord actually admitted on TV in 1992 that judges tend to look for "chaps like ourselves". Following the legal literature, we will refer to this possibility as 'self-cloning'. With this micro-foundation for favouritism in mind, we also construct a connectivity status variable to measure whether a judge has the same narrowlydefined background as any members of the promotion committee. To illustrate, a candidate for a particular vacancy will be deemed Elite if he practiced from a top-ranking chambers but he will only be connected (at least along this dimension) if a member of the promotion committee also practiced from the same physical location.

\section{Did Senior Judges Favour Elites?}

\subsection{Unconditional Evidence}

Consistent with public perception, Figure 1 shows that Elite judges overwhelmingly dominated the senior judiciary in late 2005. The figure also shows that the percentage of Elite judges is higher as one moves up the hierarchy, suggesting that their prevalence is not just a consequence of the narrowness of the pool from which High Court judges are selected. Instead, Elite judges seem more likely to be chosen at each stage of the judicial career. The main drawback of Figure 1 is that it only includes judges serving on the last day of our sample period. In Panel A of Table 1 we study all 275

\footnotetext{
${ }^{8}$ The importance of personal ties figured prominently in the political and scholarly debate. For instance, Drewry (1998) points to the 'old-boy-network' that forms the basis of the appointment process. Similarly, continuing his evidence to the Home Affairs Select Committee (see footnote 6) the Labour MP comments: "It appears to be selfperpetuating does it not? They all know each other, many of them went to school together, most of them went to university together and they have no doubt known each other all the time dining in their various Inns of Court (...) they appear to move in very limited circles."
} 
High Court judges serving between June 1985 and December 2005. Around 30\% of these judges were promoted to the Court of Appeal, whereas 26\% retired without being promoted. Among Elite judges these percentages are $40 \%$ and $21 \%$ respectively. Strikingly, only $11 \%$ of Non-Elite judges were promoted, whereas $40 \%$ retired while still serving in the High Court. The last column in Panel A of Table 1 confirms that these differences are statistically significant.

One weakness of Panel $\mathrm{A}$ is that it does not adjust for censoring. This is important because close to $40 \%$ of our sample of High Court judges were still practicing at the end of 2005. Differential censoring among Elite and Non-Elite judges - for instance due to Non-Elite judges joining the High Court later in time- could in principle be responsible for these findings. To account for this, we take an inflow sample of 240 judges appointed between 1980 and 2005 (a subset of the stock sample of 275) and compute Kaplan-Meier survivor functions overall and separately for Elite and Non-Elite judges. The first column of Panel B reveals that the (censoring-adjusted) likelihood that a judge will be promoted within 14 years is $56 \%$. The next columns show that this likelihood is much higher for Elite judges (65\%) than for Non-Elite judges (24\%). A Log Rank test strongly rejects the hypothesis that the survivor functions are equal for Elite and Non-Elite judges.

\subsection{Empirical Strategy}

The unconditional evidence certainly supports the popular stereotype: Elite judges were more likely to be promoted. The question is whether this differential arose because promotion committees were actually favouring Elite judges or because Elite judges were better endowed with promotion-relevant characteristics. ${ }^{9}$ We attempt to shed light on this issue in a number of different ways.

First, using a simple empirical model of promotion committee behaviour, we explore whether the Elite differential is robust to controlling for the promotion criteria discussed in Section 2. In doing so, we also control for connectivity status. Suppose, as we have argued, that the most plausible micro-foundation for favouritism (if it exists) is 'self-cloning'. Then, under the favouritism interpretation, controlling for connectivity should reduce the size of the Elite differential. Next, using the same empirical model, we examine situations where the committee faces a greater need to promote a candidate of high ability. If the Elite differential is truly the result of favouritism, we should expect the committee to indulge in it less when the Court of Appeal is relatively starved

\footnotetext{
${ }^{9}$ In posing this question we have not ruled out the possibility that promotion committees were favouring Non-Elite candidates. If Elite candidates were better endowed with promotion relevant characteristics, then the favouring of Non-Elite judges could still produce a raw Elite differential.
} 
of talent, say due to the loss of an able judge to the House of Lords, than in the normal course of affairs. ${ }^{10}$ In sum, we should see a lower Elite differential for 'high stakes' vacancies generated by promotions relative to those generated by retirements or new posts. Finally, we examine the behaviour of the promoted judges themselves. Under the favouritism interpretation, a Non-Elite candidate must have some other compensating characteristic, such as ability, to be selected over an Elite candidate. As such, we should expect the average promoted Non-Elite judge to be more able than the average promoted Elite judge (Lazear and Rosen 1990). This observation motivates our final test: a comparison of the performance of Elite and Non-Elite judges after joining the Court of Appeal.

\subsection{Discrete Choice Results}

In choosing an empirical model we balance a desire to capture institutional details - in particular the relative performance evaluation implicit in a committee selecting a candidate from the current stock of High Court judges - with constraints imposed by the small sample size. Our specification, McFadden's choice model, has some attractive features (e.g. the freedom to estimate on a subset of alternatives) but does impose some strong assumptions. We discuss this modelling choice in Section 3.5, after we have presented our results.

Empirical Model Consider a promotion committee $n$ that forms to fill a vacancy arising in the Court of Appeal. The set of alternatives facing this committee is the current stock of High Court judges. Letting $U_{n j}$ denote the utility this committee derives from choosing alternative $j$, its choice problem is to maximise $U_{n j}=V_{n j}+\varepsilon_{n j}$, where $V_{n j}$ is known by the researcher up to some parameters and $\varepsilon_{n j}$ is known to the committee but treated by the researcher as random. Given this choice problem, the probability that promotion committee $n$ chooses alternative $i$ is

$$
P_{n i}=\operatorname{Pr}\left[\varepsilon_{n j}-\varepsilon_{n i}<V_{n i}-V_{n j}, \quad \forall j \neq i\right]
$$

We proceed on the assumption that we can specify $V_{n j}$ sufficiently well such that the unobserved portion of utility for one alternative provides no information about the unobserved portion of utility for another alternative (i.e. the $\varepsilon_{n j}$ are independent over $j$ ). Given a further assumption that these

\footnotetext{
${ }^{10}$ Clearly, it is always desirable to select able judges for the Court of Appeal. The specific assumption here is that this objective should receive higher weight, relative to other possible objectives such as the favouring of Elite candidates, when the Court of Appeal is relatively starved of talent.
} 
unobserved portions of utility are iid extreme value, (1) can be re-written as the standard Logit choice probability (McFadden 1974)

$$
P_{n i}=\frac{\exp \left(V_{n i}\right)}{\sum_{j} \exp \left(V_{n j}\right)}
$$

We adopt the standard linear in parameters form $V_{n j}=\beta^{\prime} \mathbf{x}_{n j}+c_{j}$, where $\mathbf{x}_{n j}$ is a vector of observables that vary over alternatives and committees, and $c_{j}$ is an alternative-specific constant which ensures that $\varepsilon_{n j}$ has zero mean. Table 2 provides summary statistics for the variables included in $\mathbf{x}_{n j}$. The probability of committee $n$ choosing the alternative that we observe it choose is

$$
\prod_{i}\left(P_{n i}\right)^{y_{n i}}
$$

where $y_{n i}=1$ if committee $n$ chose $i$ and zero otherwise. Assuming that promotion committees act independently, ${ }^{11}$ the $\log$ of the probability of observing our choice data is

$$
\log L(\beta, \gamma, \mathbf{c})=\sum_{n=1}^{N} \sum_{i} y_{n i} \ln P_{n i}
$$

where $\mathbf{c}$ is a vector of alternative-specific constants.

Maximisation of (4) to obtain parameter estimates would be straightforward were it not for the fact that promotion committees face a large number of alternatives. Given statutory increases in the size of the High Court, the number of alternatives also varies over committees; e.g. a committee meeting in 1985 faces 76 alternatives, while a committee meeting in 2005 faces 108 alternatives. To conserve degrees of freedom, we estimate the model on a subset of alternatives. Following this standard methodology (see, e.g., Train 2003, Section 3.7) we take 5 random draws without replacement from the set of unchosen alternatives at the date of each vacancy and then add these to the 85 chosen alternatives to give a total sample size of $510 .^{12}$ Since all alternatives have the same chance of being selected into the subset, (4) is still the appropriate log likelihood function for our selected data (see Train 2003, p. 68-70).

Results The first column of Table 3 confirms our earlier finding that having an elite background is associated with a higher likelihood of promotion. The exponential of the coefficient gives an

\footnotetext{
${ }^{11}$ Ruling out preferences for conformity or non-conformity, this really only requires that past committee choices do not place meaningful constraints on current choices, i.e. that there are enough similar alternatives.

${ }^{12}$ We exclude non-meaningful alternatives with less than 2 years experience or who exit on the same day. Taking 10 random draws without a replacement delivers qualitatively similar results (available in the online appendix).
} 
indication of magnitude. In this unconditional baseline specification, elite status is associated with a 3.8-fold increase in the odds of an alternative being chosen for promotion by a given committee.

In the second column we include controls for the official promotion criteria. Both age at entry and experience in the High Court are included in quadratic form. 'Ability as evidenced by sound judgements' is proxied by the percentage of a candidate's prior cases that have been reversed (affirmed) by a member of the promotion committee. ${ }^{13}$ We attempt to capture the match between legal specialism and the needs of the Court of Appeal in two different ways. First, we ascertain whether an alternative and the departing Court of Appeal judge (if there is one) share the same High Court division. To illustrate, consider a committee charged with filling a vacancy created by the departure of a Court of the Appeal judge who served in the Chancery division while in the High Court. By this definition, we would expect roughly $15 \%$ of this committee's alternatives to match on legal specialism. Second, to reflect heterogeneity in work undertaken by judges appointed to the Queen's Bench Division, we divide each alternative's prior cases into seven court/legal subject categories and include the number of cases in six of these categories together with the total number of cases. ${ }^{14}$

Including these promotion-relevant characteristics more than halves the estimated change in odds from 3.84 to 2.42 (noting than the baseline change in odds is one). The reasons for the marked decline in the Elite differential are apparent in Table 2. Elite judges are on average two years younger when they enter the High Court. This is an advantage because of the committee's need to consider "the scope for further promotion". Elite judges are also more likely to hear cases in, and hence have "expert knowledge of", public and civil law. Given the dramatic rise in judicial reviews and the fact that High Court judges assist with criminal but not civil cases in the Court of Appeal, these are precisely the areas of expertise most in need in the Court of Appeal.

Interpreting these results is not a straightforward task. The fact that the Elite coefficient remains significant after controlling for promotion criteria could be read as evidence of favourtism. However, the large decline in the Elite coefficient suggests that at least part of this differential may be due to omitted variables, particularly as our proxies for promotion criteria are imperfect. We return to this important issue in Table 4, after discussing the remaining columns of Table 3.

\footnotetext{
${ }^{13}$ These measures of ability are undoubtedly imperfect and might themselves be contaminated by favouritism. We include them to be as comprehensive as possible but emphasise that they are rarely significant.

${ }^{14}$ While we interpret the number of cases in each category as legal specialism, another possibility is non-random case allocation. Further results (available upon request) suggest that this is unlikely as our court-subject measures are highly correlated with measures that pre-date appointment, e.g. the judge's self-reported specialism as a barrister.
} 
In the third column we investigate whether sharing a narrowly defined background with members of the promotion committee increases a candidate's chances of promotion (the leading microfoundation for the favouritism hypothesis). We consider four dimensions: whether the candidate (i) attended the same school, (ii) attended the same university (college if Oxford or Cambridge), (iii) practiced from the same chambers or (iv) belonged to the same (sporting or gentleman's) club as any member of the promotion committee. Our connectivity measure to the Lord Chancellor (Heads of Division respectively) is the percentage of these dimensions that the candidate is connected to the Lord Chancellor (average Head of Division). Note from Table 2 that Elite judges are, naturally, much more connected than Non-Elite judges. The results in Table 3 show that, contrary to what one would expect under the favouritism hypothesis, judges with strong personal ties to the Heads of Division are less likely to be promoted. The coefficient is economically as well as statistically significant: a standard deviation increase in connectivity to the Heads of Division is associated with a fall in the odds of being selected from one to $.73=\exp (-6.072 * .05)$. On the other hand, being connected to the Lord Chancellor does not seem to affect a candidate's chances of promotion.

Finally, in the fourth column, we find no evidence that the Elite differential is lower for 'high stakes' vacancies generated by promotions from the Court of Appeal. Thus, it does not seem as if Non-Elite judges are more in demand when the Court of Appeal is relatively starved of talent. ${ }^{15}$

In Table 4, we re-run the specifications in the first two columns of Table 3 using a set 'Route to the Bench' dummies in place of the binary 'Elite' variable. Panel A repeats the coefficients from Table 3 for ease of comparison; Panel B reports results using State-Other as the excluded category; while Panel C reports results using Private-Oxbridge-Top-Ranking as the excluded category. The first column shows that the partial effect of a private education on the odds of promotion varies with subsequent occupational location. For the Other categories the effect of a private education is positive and weakly significant (second row Panel B), while for the Oxbridge-Top-Ranking categories the sign of the effect is negative but it is not statistically different from zero (third row Panel C). The inclusion of promotion-relevant characteristics has little impact on these coefficients, as one would expect if parents choose (and can afford) to send their children to private school for reasons other than subsequent judicial ability. This column also shows that the partial effect of attending Oxbridge and then practicing from a top-ranking chambers varies with previous education. For the State categories the effect is positive and strongly significant (third row Panel B), while for

\footnotetext{
${ }^{15}$ This is true even when we control for the elite status of the departing judge to account for potential favouritism in the promotion from the Court of Appeal to the House of Lords.
} 
the Private categories the sign of the effect is positive but it is not statistically different from zero (second row Panel C). The inclusion of promotion-relevant characteristics reduces both coefficients, precisely as one would expect if top law schools and legal chambers select on the basis of subsequent judicial ability. In the State case, the effect remains positive but is no longer significant, while in the Private case the effect becomes negative but remains insignificant.

The results in Table 4 cast further doubt on the favouritism interpretation of the unexplained Elite differential. First, if either education or occupation-based favourtism was an important force, then we should see a significant difference between the Private-Oxbridge-Top-Ranking and StateOther categories that persists after controlling for promotion criteria. However, although the raw change in odds of 2.67 is significant, it falls to 1.75 and is no longer significant once we include promotion-relevant characteristics. Second, if education-based favouritism was the predominant force, then we should see a persistent difference between the Private-Other and State-Other categories. In this case, the raw factor change in odds is stable but smaller and only weakly significant. Third, if occupation-based favouritism was the predominant force, then there should be a persistent difference between the State-Oxbridge-Top-Ranking and State-Other categories. Again, although the raw change in odds of 5.33 is significant, it falls to 2.92 and is no longer significant once we include promotion-relevant characteristics. Given the magnitude of this fall (and the natural interpretation that these state-educated judges differ in terms of ability), our view is that the unexplained Elite differential is more likely to be due to omitted variables. We do, of course, acknowledge that this something of a grey area and hence proceed to consider other evidence.

\subsection{Post Promotion Results}

Measuring Performance We compare the performance of judges after joining the Court of Appeal in terms of positive voluntary citations by other judges in unrelated cases. While positive citation counts are not the sole measure of judicial productivity, they capture the most important dimension of a Court of Appeal judge's work, namely the clarification and expansion of the law and its legal principles. ${ }^{16}$ There may be other dimensions which, unfortunately, we cannot measure. As a result, the empirical exercise below should not be viewed as the ultimate test for the existence of favouritism, but rather as evidence to be evaluated together with that from other sections. Before discussing econometric concerns, we first explain the concept of a positive voluntary citation.

\footnotetext{
${ }^{16}$ The legal literature also favors citation counts over other measures of senior judicial performance. See Choi and Gulati (2004), Posner (2005) and the Florida State University Review Special Issue in 2005.
} 
The citations in our database come pre-coded by lawyers at Westlaw. Almost all are positive or neutral and fall into one of three categories: 'applied', 'followed' and 'considered'. The label 'applied' is assigned when the principles of law in the annotated case have been applied to a new set of facts and circumstances; that is, when the citing judge did not have to (since the facts and circumstances of his case were different), but nevertheless chose to, use the principles of law developed in the cited case. Arguably, legal principles of the cited case were 'applied' because they were more sound, useful, persuasive and original than those in other cases. The label 'followed' is assigned when the citing judge is bound by the rule of precedent. Since a judge who is obliged to apply the legal principles of an earlier case is not necessarily endorsing them, we do not use 'followed' citations as evidence of good performance. Finally, the label 'considered' is assigned when the court in the annotating case has discussed the decision in the annotated case but has not actually followed it; that is, a reference has been made to the cited case, but its legal principles have not been explicitly endorsed. Since we cannot be certain that the citation reflects good and original legal thinking by the cited judge, we also drop 'considered' citations from our measure. The dependent variables described below are therefore based solely on counts of 'applied' citations.

Econometric Concerns Clearly, if we studied the performance of judges throughout their time in the Court of Appeal, our results would be affected by ability-related attrition. That is, since the best performers leave for the House of Lords, we would end up comparing the performance of the losers of the following promotion tournament. Since the most rapid promotion in our sample occurred after 585 days, we compare the performance of judges during their first 585 days in the Court of Appeal. A further concern is that citations could be driven by strategic behaviour rather than ability. One possibility is that citation prone cases could be allocated to judges with a particular profile. Our conversations with the government agency responsible for the administration of the courts suggest that the allocation of cases in the Court of Appeal is exogenous to judicial background characteristics; the key factor is whether a judge is available when the agency is notified of the case. Further evidence that the allocation of cases is (statistically speaking) identical across groups is provided in Table A3 where we show that a rich measure of the legal subject of a case (with around 90 categories) is uncorrelated with the background of the presiding judges.

Turning to strategic citation behaviour itself, the leading possibility is that citations are more likely to occur within background groups than across them. For instance, Elite judges may be more likely to cite other Elite judges due to social preferences or better knowledge of their cases. If 
this is true, then judges belonging to the larger group (in this example the Elite group) could receive a higher number of citations, independent of their true ability. To allow for this possibility, we disaggregate our dependent variables by the elite status of the citing judge. A less plausible possibility is that a judge might cite a newly promoted Court of Appeal judge because he anticipates that this judge could (many years in the future) become a Head of Division and will remember the favour. Since members of the House of Lords no longer face career concerns, we would ideally disaggregate our dependent variable by the court of the citing judge. Unfortunately, the number of citations by law lords is sufficiently small to preclude such analysis. We do, however, use an index of intellectual influence (Palacios-Huerta and Volji 2004) as one of our dependent variables. As we discuss below, this measure over-weights citations by cases in the House of Lords and therefore partially addresses such concerns.

Empirical Models and Results Our first specification, reported in the first column of Table 5 , is a Poisson regression where we relate the number of citations that a promoted judge received (across all cases in which he was presiding during his first 585 days in the Court of Appeal) to his background characteristics. In Panel A we explore whether the average promoted Non-Elite judge performed better than the average promoted Elite judge, as would be the case if the raw Elite promotion differential was (solely) due to favouritism. In fact, we find that the Elite coefficient is positive. In view of the possible association between connectivity and promotion, we also include a dummy that takes the value 1 if the judge was connected to any member of the committee that promoted him, referring to this as 'connectivity-at-promotion' status. If Elite judges were favored and connectivity was the microfoundation, then one would expect the group that was unconnectedat-promotion to perform better post-promotion. Again, we find no such evidence. Consistent with the negative impact of connectivity reported in Section 3.3, the connected-at-promotion coefficient is positive (albeit insignificant). ${ }^{17}$

In Panel B we re-run this specification using a set of Route to Bench dummies in place of the binary Elite variable. The Private-Oxbridge-Top-Ranking, Private-Other, and State-OxbridgeTop-Ranking coefficients are all positive and significant, indicating that the average judge in each of these finer categories performed better than the average Non-Elite judge. ${ }^{18}$ As one might expect

\footnotetext{
${ }^{17}$ Anticipating the results in Section 4, the small size of the connectivity-at-promotion coefficient may be due to the omission of judges appointed after 2003 (explaining why the sample size is 61 rather than 85). With our data ending in 2005, we do not have sufficient Court of Appeal cases to calculate citation counts for these later promotions.

${ }^{18}$ We do not include Circuit as a separate category because just one of these judges was promoted.
} 
if law schools and top chambers select on the basis of judicial ability, the coefficients are slightly larger for the two Oxbridge-Top-Ranking categories than for the Private-Other category, although these differences are not statistically significant.

In the second column of both Panels A and B we include the proxies for the official promotion criteria discussed in Section 2. Including these controls reduces the State-Oxbridge-Top-Ranking coefficient (the mean response, calculated by multiplying the mean of the dependent variable 3.63 by the estimated coefficient, almost halves from 4.79 to 2.87 ) and has little impact on the PrivateOther coefficient. The changes to these two coefficients are similar to those following the inclusion of the same controls in the discrete choice model of Table 4. However, in contrast to the discrete choice model, the Private-Oxbridge-Top-Ranking, and hence the overall Elite, coefficient increases slightly after the inclusion of promotion criteria controls. Also in contrast to the discrete choice model, all coefficients remain positive and significant.

The large fall in the Elite citation differential among state-educated judges is reassuring and lends further support to the view that the raw Elite promotion differential is driven by endowments rather than favourtism. Of course, one might ask why an unexplained Elite citation differential remains for these (and the privately educated) judges. We believe the reason is that we have good measures of the first three official promotion criteria (age, experience and legal specialism) but only an imperfect measure of 'ability as evidence by sound judgements' and it is this fourth criterion that is the more important driver of citation-based performance.

A natural count of citations is a relatively coarse measure of performance, as it treats all citations equally. Since a citation by the House of Lords is almost certainly a better indicator of good performance than a citation from a lower court, it would be preferable to construct a measure where each citation is allocated an endogenously determined weight depending on the stature of the citing court. In the third column of Table 5 we use such an index of intellectual influence' as our dependent variable (with a Tobit rather than OLS specification to account for the preponderance of zeros). Our index weights each citation by the endogenously determined influence of the citing court, which is computed using the methodology characterised in Palacios-Huerta and Volij (2004). ${ }^{19}$ Using this measure as our dependent variable leaves our results (qualitatively) unchanged: Non-Elite judges and unconnected judges do not appear to be more intellectually influential upon promotion; the Elite coefficient and each of the Route to the Bench dummies is

\footnotetext{
${ }^{19}$ Details of the variable construction are provided in Appendix B.
} 
positive and significant, both with and without controls. ${ }^{20}$

At this stage the charge could still be made that strategic citation behaviour is clouding our results. In the final two columns of Table 5 we report results for our index of intellectual influence measure disaggregated by the elite status of the citing judge. If citations are more likely within background groups, then (if it exists) we should finally see evidence of favouritism in the fourth column where we focus on citations from Non-Elite judges. Again, we find no such evidence. Elite judges influence more strongly not only other Elite judges but also Non-Elite judges. This finding, together with Table A3, reinforces our confidence that Elite judges are better performers - at least on this particular dimension- than Non-Elite judges. ${ }^{21}$

\subsection{Discussion}

We stress at the outset that we do not (and given our empirical strategy could not) claim to have resolved conclusively whether senior judges favored candidates with an Elite background. Rather, we limit ourselves to the following more nuanced conclusions. Pooling over our sample period, Elite judges were substantially more likely to be promoted than Non-Elite judges. The weight of evidence suggests that this was because Elite judges were better endowed with promotion-relevant characteristics than Non-Elite judges.

Our justification for the latter claim is three-fold. First, we have found direct evidence consistent with the endowments interpretation: (i) the Elite differential more than halves once we include proxies for official promotion criteria, and (ii) newly promoted Elite judges exerted stronger intellectual influence on both Elite and Non-Elite judges than newly promoted Non-Elite judges. Second, we have found direct evidence inconsistent with the favouritism interpretation (at least in the 'self-cloning' form referred to in legal and policy circles): sharing the same narrowly defined background with members of the promotion committee was associated with a lower chance of promotion. Third, we failed to find direct evidence consistent with the favouritism hypothesis: the Elite differential is not lower for high stakes vacancies. The only evidence in favour of the favouritism hypothesis is indirect (at best, especially given our imperfect proxy for ability): the

\footnotetext{
${ }^{20}$ Results for the specifications without controls are available in the supplementary online appendix.

${ }^{21}$ We have repeated the analysis using other types of citation. For positive citations dictated by precedent ('followed') we find qualitatively similar (albeit quantitatively weaker) results, while for neutral ('considered') citations, we find no statistically significant effect. We have also repeated the analysis at case-level by relating the number of positive citations that a Court of Appeal case received to the background of the presiding judge. The results of both robustness checks are available in the supplementary online appendix.
} 
small residual Elite differential could still be due to favouritism.

In view of the small sample size, we have used an empirical strategy that is simple and hence open to criticism. In particular, one might point to the independence of irrelevant alternatives property of the discrete choice model. We use the logit specification because it allows us to estimate on a subset of alternatives (the full set is greater than $N=85$ ). In our setting, it seems reasonable that adding another alternative (effectively a 'slot' that is not intrinsically any more or less like any other) would leave the ratio of choice probabilities unaffected and result in proportionate substitution. Consistent with this, the dramatic reduction in the Elite differential is also present in a survival framework that, by construction, does not impose IIA. ${ }^{22}$

\section{Did Senior Judges Change Behaviour in the Face of Reform?}

In Section 3 we examined the hypothesis that senior English judges showed a lack of discipline by favouring Elite candidates for promotion to the Court of Appeal, and found little evidence in its favour. If anything, the evidence suggested that these judges wished to avoid allegations of favourtism, as personal ties to the committee were associated with a lower chance of promotion.

This was not the view held by many politicians, lobby groups and press commentators. As Appendix $\mathrm{C}$ describes in detail, allegations of elitism and calls for an independent appointments commission were common place throughout our sample period. Senior judges were strongly opposed to reform, openly stating their reluctance to cede control over promotions, and until 2003 managed to kill in the ground all such attempts by both Conservative and Labour governments. On June 12 2003, however, the Labour Prime Minister unexpectedly announced that a new body would take responsibility for judicial appointments, including promotions to the Court of Appeal. As we argue in Appendix $\mathrm{C}$, the specific composition of this new body was subject to considerable uncertainty for nearly two years, with alternative proposals -in which judges held very different levels of influence- being considered. Since senior judges actively lobbied to influence the final composition of the new body, it is reasonable to hypothesize that any perception of favouritism during this period would have been damaging to their case.

The purpose of this Section is to investigate whether this hypothesized increase in the returns to minimizing perceptions of favouritism affected promotion decisions in the period after June 2003. In doing so, we highlight that neither the official criteria for promotion nor the identity of the Heads

\footnotetext{
${ }^{22}$ Results from survival models are reported in earlier versions of this paper, and are available upon request.
} 
of Division forming the committee changed in June 2003. In particular, the same Heads of Division - a group that we will call the 'Heads at Announcement' - had been in charge since July 2000 and remained in their posts until after the reform passed into law in March $2005 .{ }^{23}$

\subsection{Empirical Strategy and Results}

We use the discrete choice model outlined in Section 3.3 to examine the conditional evidence for a change in promotion committee behaviour following the announcement of the reforms. We do so by interacting the main independent variables of interest with a dummy 'Reform' that captures whether a promotion committee made its decision after June $2003 .{ }^{24}$

The first column of Table 6 contains a single interaction with the binary 'Elite' variable. The sign of the coefficient 'Elite*Reform' is negative and statistically significant, indicating a large change following the announcement of the reforms. The Elite differential is positive during the baseline period but actually becomes negative during the post-announcement period.

In the second column we add interactions with our main connectivity variable. The negative coefficient 'Connectivity to Heads' indicates that being strongly connected to the Heads of Division decreased a candidate's chances of promotion in the baseline period. The negative coefficient 'Connectivity to Heads*Reform' suggests that connectivity decreased these chances even more during the post-announcement period. The change in behaviour is economically as well as statistically significant: an increase in connectivity of one standard deviation decreases the odds of being promoted from one to $.801=\exp (-4.437 * .05)$ during the baseline period but to a significantly lower $.173=\exp ((-30.605-4.437) * .05)$ during the post-announcement period.

In the third column of Table 6 we add interactions with the type of vacancy. The introduction of these triple interactions calls for some care in interpreting the coefficients. For instance, the coefficient 'Elite' should now be interpreted as the Elite differential for Court of Appeal vacancies generated as a result of a retirement during the baseline period. The statistically insignificant

\footnotetext{
${ }^{23}$ There is one caveat: the identity of the Lord Chancellor did change in June 2003. However, recall from Table 3 that connectivity to the Heads of Division determines a candidate chances of promotion, while connectivity to the Lord Chancellor plays no role. This, together with the quotes from Section 2, suggests that in practice promotion decisions are delegated to the Heads of Division.

${ }^{24}$ We have also re-run the specifications in Table 3 on pre-June 2003 and post-June 2003 sub-samples (see the supplementary online appendix). This exercise is complicated by the small number of promotions in the latter period (prompting us to use a subset of controls) but supports the conclusions presented below. We cannot repeat the interaction/sub-sampling analysis for the post-promotion model for the reasons stated in footnote 17.
} 
'Elite*Promotion Vacancy' coefficient suggests that, during the baseline period, the Elite differential did not vary with the type of vacancy. Similarly, the sum of the coefficient 'Elite' and 'Elite*Reform' (i.e. $-2.512=1.798-4.310$ ) captures the Elite differential for retirement vacancies during the post-announcement period. The sum of the four coefficients (i.e. $1.596=1.798-4.310-1.496+$ 5.604) captures the Elite differential for promotion vacancies during the post-announcement period. Testing whether the sum of 'Elite*Promotion Vacancy' and 'Elite*Promotion Vacancy*Reform' is equal to zero is therefore equivalent to testing whether, during the reform period, the Elite differential varied with the type of of vacancy. We reject the null hypothesis of this test at the $10 \%$ level $(p$-value= .059$)$. This provides weak evidence that, during the post-announcement period, Elites were more likely to be selected to fill promotion vacancies than retirement vacancies. ${ }^{25}$

\subsection{Discussion}

There are two separate issues to discuss here: whether Non-Elite/unconnected judges were more likely to be promoted and, if so, whether any such finding can really be attributed to a change of behaviour following the threat of reform. There is certainly evidence of the former. Controlling for promotion criteria, the Elite differential changed sign from positive to negative in the period after June 2003. In contrast, most of our proxies for promotion-relevant characteristics did not change during this period. For an omitted quality variable to explain the increase in fortune of the Non-Elite, it would therefore have to be orthogonal to the measures suggested by the Judges' Council. ${ }^{26}$ Similarly, we see that the connected differential changes from being small and only weakly significant to strongly negative in the period after June 2003. Arguably, it is even harder to attribute this change to omitted (Non-Elite) candidate quality; given our other controls, variation in connectivity status is essentially driven by committee characteristics.

The issue of attribution is far harder to resolve. The most obvious alternative to a change of behaviour in response to the threat of reform is that we have observed an unexpected form of ill-discipline, whereby the promotion committee suddenly started to prefer to appoint Non-Elite candidates. We feel this is unlikely. First, we found no suggestion of this possibility among the

\footnotetext{
${ }^{25}$ An alternative way of interpreting these coefficients is to note that the post-announcement period led to a decrease in the likelihood of Elites filling retirement vacancies (the p-value of the 'Elite*Reform' coefficient is .001) but did not lead to a decrease in the likelihood of Elites filling promotion vacancies (testing whether the sum of 'Elite*Reform' and 'Elite*Promotion Vacancy*Reform' is zero we obtain a p-value of .532).

${ }^{26}$ The few proxies that changed did so by making Elite judges even better candidates relative to the Non-Elite. The aforementioned omitted quality variable would therefore have to be negatively correlated with these variables.
} 
political and academic commentary during this period. Second, the same Heads of Division were in place from July 2000 until April 2005. Historically, this group held the balance of power within the committees and, as we have argued, previously appeared to have been disciplined or congruent. Interpreting our findings as reflecting the true preferences of the promotion committee would require claiming that the same Heads of Division somehow changed their preferences dramatically in June 2003. Third, although the overall composition of the committee did change, the only prominent new member - a new Lord Chancellor - both played a small role in the actual decisions and stood to gain little from imposing his preference as his position was to be abolished as part of the reforms.

We conclude by pointing to one final piece of evidence against the stereotypical claim that senior judges favored Elites. The change in the Elite differential was different depending on the nature of the vacancy generated in the Court of Appeal. While it decreased for 'low stake vacancies' - those generated by a Court of Appeal judge exiting into retirement or the statutory creation of a new post- it remained unchanged for 'high stake vacancies', generated as a result of a promotion. Consequently, while the Elite differential was statistically similar for both types of vacancies during the baseline period, it became much higher for promotion vacancies relative to retirement vacancies during the post-announcement period. This finding that Elite judges were more likely to access

'high stakes' vacancies even in the post-announcement period provides further evidence against the hypothesis of favouritism discussed in Section 3. During the post-announcement period, promoting Non-Elite judges arguably became more attractive. However, this did not appear to have translated into an increase in Non-Elites accessing 'high stake vacancies'. It seems that another force - higher merit or endowment of promotion-relevant characteristics- was acting as a countervailing force.

\section{Concluding Remarks}

This paper has addressed two empirical questions. Did senior judges show a lack of discipline by favouring Elites? And did senior judges avoid seeming to favour Elite candidates when faced with the prospect of reform? Our answers to both questions are qualified given the limitations of the available data. To the first, we say unlikely. And to the second, quite possibly.

At a general level, these findings contribute to our understanding of the incentives and behaviour of public officials. As we noted in the Introduction, a growing theoretical literature has analysed the decision-making distortions that can arise when informed politicians wish to signal congruence of preferences with voters. Tenured public officials are assumed to be shielded from 
such distortions arising from the need to please a constituency, whether voters or their representatives. Although there is anecdotal evidence, such as the 'switch in time that saved nine', to suggest that this assumption may not be correct, this paper is, to the best of our knowledge, the first to document econometrically that the behaviour of tenured public officials can change in response to a possible loss of decision-making power. As a result, our findings cast doubt on the wisdom of drawing sharp distinctions between "judges" and "politicians".

On this point, we note a somewhat forlorn postscript to the English experience of constitutional reform. Barely two years after it was introduced, the work of the new judicial appointments commission has been criticised. Tellingly, the chair of the Home Affairs Select Committee recently remarked that, in terms of appointing candidates with a less traditional background, the new system is "actually worse" than the previous system under higher judicial influence. ${ }^{27}$ Responding to claims that, despite their reduced influence, judges have still been managing to favour Elite and well-connected candidates, the Government is currently proposing to hand even more control to lay commissioners. Our evidence that senior judges were, if anything, favouring Non-Elite candidates under the previous system offers an alternative explanation for the 'poor' performance of the commission, and suggests the further reforms will not be a quick fix. Rather, the data indicate that attention would be better focused on widening access at the early stages of a legal career.

Finally, it is worth emphasising that global interest in the way that judges are selected has increased dramatically over the last two decades, suggesting that our results may also be relevant for policy in other countries. One reason for this interest is the rise in judicial activism brought about, in common law countries, by human rights legislation that has enshrined the right to judicial review and, in civil law countries, by the willingness of magistrates to investigate corruption charges against politicians (Malleson 2006). A second reason is the growing realisation that judges are unrepresentative of the societies whom they serve (see, e.g., Handsley 2006 and Du Bois 2006). This combination of powerful, unrepresentative and, in most jurisdictions, unelected judges has prompted debate as to the best way to safeguard judicial independence from politicians while guaranteeing accountability to voters (the fraught relationship between the Knesset and the Israeli judicial appointments commission discussed in Section 2 being a case in point). Our finding that England's (effectively) self-appointing judiciary appears to have been both more congruent, and at times more responsive to political pressure, than previously thought should offer a valuable lesson for this global debate.

\footnotetext{
${ }^{27}$ Quoted in "The first ten High Court judges under new diversity rule", The Guardian, January 282008.
} 


\section{References}

[1] Alesina, A. and Tabellini, G. (2007), "Bureaucrats or Politicians? Part I: A Single Policy Task" American Economic Review, 97(1): 169-179.

[2] Allan, J. (2006), “Judicial Appointments in New Zealand: If it were done when 'tis done, then 'twere well it were done openly and directly" in Malleson, K. and Russell, P. (eds.) Appointing Judges in an Age of Judicial Power, Toronto University Press.

[3] Altonji, J. and Blank, R. (1999), "Gender and Race in the Labor Market ", in Ashenfelter, O. and Card, D. (ed), Handbook of Labor Economics, New York: Elsevier Science Press.

[4] Bagues, M. and Esteve-Volart, B. (2007), "Can Gender Parity Break the Glass Ceiling? Evidence from a Repeated Randomized Experiment", mimeo, Universidad Carlos III and York University.

[5] Barro, R. (1973), "The Control of Politicians: An Economic Model", Public Choice, 14: 19-42.

[6] Bell, J. (2003), "Judicial Appointments: Some European Experiences", mimeo.

[7] Bertrand, M. and Mullainathan, S. (2004), "Are Emily and Greg More Employable that Lakisha and Jamal? A Field Experiment on Labor Market Discrimination", American Economic Review, 94: 19-42.

[8] Besley, T. (2006), Principled Agents? The Political Economy of Good Government, Oxford University Press.

[9] Besley, T. and Coate, S. (2003), "Elected versus Appointed Regulators: Theory and Evidence", Journal of the European Economic Association, 1: 1176-1206.

[10] Canes-Wrones, B., Herron, M. C., and Shotts, K. W. (2001), "Leadership and Pandering: A Theory of Executive Policy Making", American Journal of Political Science, 45(3): 532-50.

[11] Choi, S. and Gulati M. (2004), “A Tournament of Judges?”, California Law Review, 92: 299.

[12] Choi, S., Gulati M. and Posner E. (2010), "Professionals or Politicians: the Uncertain Empirical Case for an Elected Rather than Appointed Judiciary", Journal of Law, Economics, and Organization, 26: 290-336.. 
[13] De Groot-Van Leeuwen, L. (2006), "Merit Selection and Diversity in the Dutch Judiciary" in Malleson, K. and Russell, P. (eds.) Appointing Judges in an Age of Judicial Power, Toronto University Press.

[14] Department for Constitutional Affairs (2005), Judicial Appointments Procedures available at www.dca.gov.uk/judicial/appointments/jappinfr.htm

[15] Drewry, G. (1998), "Judicial Appointments", Public Law, Spr: 1-7.

[16] Du Bois, F. (2006), "Judicial Selection in Post-Apartheid South Africa" in Malleson, K. and Russell, P. (eds.) Appointing Judges in an Age of Judicial Power, Toronto University Press.

[17] Eggertsson, G. and Le Borgne, E. (2007), "Dynamic Incentives and the Optimal Delegation of Political Power", IMF Working Paper No. 07/91.

[18] Ferejohn, J. (1986), "Incumbent Performance and Electoral Control", Public Choice, 50: 5-25.

[19] Gadbois, G. (1968), "Indian Supreme Court Judges: A Portrait", Law 85 Society Review, 3(2/3): $317-336$.

[20] Gordon, S. and Huber, G. (2007), "The Effect of Electoral Competitiveness on Incumbent Behavior", Quarterly Journal of Political Science, 2: 107-138.

[21] Handsley, E. (2006), "The judicial whisper goes around': Appointment of Judicial Officers in Australia" in Malleson, K. and Russell, P. (eds.) Appointing Judges in an Age of Judicial Power, Toronto University Press.

[22] House of Commons Home Affairs Select Committee 1995-1996, “Judicial Appointments Procedures" Third Report, HC 52-I.

[23] Hulsebosch, D. (1990), "The New Deal Court: Emergence of a New Reason", Columbia Law Review, 90: 2016-25.

[24] Iaryczower, M., Lewis, G. and Shum, M. (2010), "To Elect or to Appoint? Bias, Information, and Responsiveness of Bureaucrats and Politicians", mimeo.

[25] The Judges' Council (2003), “Judges' Council Response to the Consultation Papers on Constitutional Reform" available at http://www.dca.gov.uk/judicial/pdfs/jcresp.pdf. 
[26] Landfried, C. (2006), "The Selection Process of Constitutional Court Judges in Germany" in Malleson, K. and Russell, P. (eds.) Appointing Judges in an Age of Judicial Power, Toronto University Press.

[27] Lazear, E. and Rosen, S. (1990) "Male-Female Wage Differentials in Job Ladders", Journal of Labor Economics, 13: 426-471.

[28] Lim, C. (2010), "Turnover and Accountability of Appointed and Elected Judges", mimeo.

[29] Maskin, E. and Tirole, J. (2004), "The Politician and the Judge: Accountability in Government", American Economic Review, 94(4): 1034-54.

[30] McFadden, D. (1974), "Conditional Logit Analysis of Qualitative Choice Behaviour", in Zarembka, P. (ed), Frontiers in Econometrics, Academic Press.

[31] Malleson, K. (2000), "Promoting Diversity in the Judiciary: Reforming the Judicial Appointments Process" in Thomas, P. (ed) Discriminating Lawyers, Cavendish Press.

[32] Malleson, K. (2004), "Creating a Judicial Appointments Commission: Which Model Works Best?", Public Law, 102-121.

[33] Malleson, K. (2006), "The New Judicial Appointments Commission in England and Wales: New Wine in New Bottles?" in Malleson, K. and Russell, P. (eds.) Appointing Judges in an Age of Judicial Power, Toronto University Press.

[34] Neuborne, B. (2003), "The Supreme Court of India", International Journal of Constitutional Law, 476-511.

[35] O'Brien, D. (2006), "The Politics of Judicial Selection and Appointments in Japan and Ten South and Southeast Asian Countries" in Malleson, K. and Russell, P. (eds.) Appointing Judges in an Age of Judicial Power, Toronto University Press.

[36] Palacios-Huerta, I. and Volij, O. (2004), "The Measurement of Intellectual Influence", Econometrica, 72(3): 963-977.

[37] Paterson, A. (2006), "The Scottish Judicial Appointments Board: New Wine in Old Bottles?" in Malleson, K. and Russell, P. (eds.) Appointing Judges in an Age of Judicial Power, Toronto University Press. 
[38] Peach, L. (1999), "Independent Scrutiny of the Appointment Processes of Judges and Queen's Counsel in England and Wales", available at http://www.dca.gov.uk/judicial/peach/indexfr.htm.

[39] Persson, T. and Tabellini, G. (2003), The Economic Effects of Constitutions, MIT Press.

[40] Posner, R. (2005), "Judicial Behaviour and Performance: An Economic Approach", Florida State University Law Review, 32: 1259-1280.

[41] Price, J. and Wolfers, J. (2007), "Racial Discrimination among NBA Referees", NBER Working Paper, 13206.

[42] Ramseyer, M. (1997), "The Puzzling (In)dependence of Courts: A Comparative Approach ", Journal of Legal Studies, 23: 721-747.

[43] Salzberger, E. (2006), "Judicial Appointments and Promotions in Israel: Constitution, Law and Politics" in Malleson, K. and Russell, P. (eds.) Appointing Judges in an Age of Judicial Power, Toronto University Press.

[44] Schultz, C. (2008), "Information, Polarization and Delegation in Democracy", Journal of Public Economics, 92(5): 1078-91.

[45] Shea, C. (2005), "Did FDR's threat to 'pack' the court in 1937 really change the course of constitutional history?", The Boston Globe, December 4.

[46] Thomas, C. (1997), "Judicial Appointments in Continental Europe", in Malleson, K. and Thomas, C., Judicial Appointments Commissions: The European and North American Experience and the possible implications for the United Kingdom, discussion papers prepared for the Lord Chancellor's Department.

[47] Train, K. (2003), Discrete Choice Methods with Simulation, Cambridge University Press.

[48] Volcansek, M. (2006), "Judicial Selection in Italy: A Civil Service Model with Partisan Results" in Malleson, K. and Russell, P. (eds.) Appointing Judges in an Age of Judicial Power, Toronto University Press. 


\section{Appendix}

\section{A International Comparison of Judicial Appointment Procedures}

Every method of judicial appointment attempts to strike a balance between guaranteeing the independence of the judiciary and maintaining a certain amount of 'accountability', a democratic link providing the judiciary with legitimacy. This balance naturally takes different forms in different jurisdictions, depending on legal traditions, political culture, and the idiosyncrasies of history. For instance, the staunch independence of the Italian judiciary emerged after the second world war as a response to the political co-opting of the judiciary during the Mussolini regime (Volcansek 2006).

Perhaps the easiest way to characterize systems of appointment is on the basis of the institution holding the notional authority over the final decision. Four major systems emerge: appointment by democratically elected representatives, self-appointing judiciaries, direct election by citizens, and appointment by judicial (mixed) commissions. One important point to note, however, is that often notional authority and real authority differ significantly. In many jurisdictions, the party with formal (notional) authority effectively rubber stamps the proposal made by another better informed party. We discuss some of these cases below.

Elected Representatives The method of appointment by elected representatives (either the executive or the legislature) is found mostly for appointments to constitutional or supreme courts. In Germany, for instance, Constitutional Court judges are selected by Parliament through a supermajority requirement, which has led to a reciprocity system whereby seats are in practice reserved for particular parties (Landfried 2006). In Australia and New Zealand it is instead a member of the executive (the Attorney General) that makes senior appointments (Allan 2006, Handsley 2006).

In many civil law systems (e.g. Spain, France, Portugal, Italy) Constitutional Courts positions are allocated to different branches of government through a quota system. In other jurisdictions (US, Brazil) different branches of (elected) government must cooperate during the appointment process in the filling of each vacancy. Most famously, US Supreme Court judges are nominated by the President but must then be ratified (an outcome by no means guaranteed) by the Senate.

As noted above, the judiciary often holds the real authority over the appointment decision even though the formal authority belongs to an elected office. Political traditions and conventions imply that, in practice, the elected body always rubber stamps the proposal made by the judiciary. In Japan, for instance, appointments are formally made by the prime minister and cabinet, but in 
practice they have always accepted the recommendation made by the Chief Justice of the Supreme Court (O'Brien 2006). ${ }^{28}$ In the Netherlands, Supreme Court justices present Parliament with a list of six candidates to fill one vacancy, and Parliament always appoints the candidate at the top of the list (De Groot-Van Leeuwen 2006). As we argued in Section 2 in the English system prior to 2006 senior judges enjoyed significant influence in promotions from the High Court to the Court of Appeal, even though formal responsibility lay with the Lord Chancellor, a political appointee.

Self-Appointing Judiciary The judiciary holds formal control over appointments to senior positions in only a few countries. In India, initial ambiguity over the responsibility to appoint Supreme Court judges was resolved by two important Supreme Court decisions in 1994 and 1999, which gave ultimate power to a committee consisting of the Chief Justice and the four most senior Supreme Court justices (Neuborne 2003). Formal judicial self-selection is much more prevalent in the lower rungs of the judicial hierarchy, however. In Japan, the Supreme Court Secretariat has complete control over appointments and promotions below the Supreme Court level, although they can afterwards be voted out by citizens (O'Brien 2006). In Italy the independence of the judiciary is enshrined in the 1948 Constitution. The Constitution also establishes that assignments and promotions (with the exception of the Constitutional Court) are governed by the Superior Council of the Magistrature, two thirds of which is composed of judges elected by their peers, with the other third named by the two Houses of Parliament (Volcansek 2006).

Direct Election Direct election by citizens occurs in some US states and takes two main forms, depending on whether elections are used for the initial appointment or only for confirmation. The first system closely resembles election to political offices, in that several candidates often run for office, judges are associated with political parties and money is raised to finance the election campaign. The resulting politicization of judicial offices has prompted concerns that the balance is tilted excessively towards the accountability of judges and at the cost of their independence. Alternatively, some states have introduced versions of the 'Missouri plan', whereby the state governor chooses a judge (from a list offered by a judicial commission) whenever a vacancy arises, but then this judge must be ratified by voters around a year after being appointed. Some states uses different

\footnotetext{
${ }^{28}$ The Japanese judiciary has typically been composed of judges with an ideology very similar to that of the ruling Liberal Democratic Party. Ramseyer (1997) argues that the government holds significant influence over the appointment process even while seeming to defer to the judiciary's proposal on every occasion.
} 
systems in different districts. In practice, judges are rarely recalled, however. ${ }^{29}$

Judicial Appointments Commissions The use of purposely created judicial commissions is supposed to strike a balance between independence and accountability. For this reason, judicial commissions are becoming increasingly popular around the world. Judicial commissions isolate the decisions (either notionally or in practice) from the political process. ${ }^{30}$ The members of the commission are (at least partly) selected by elected politicians, which provides an indirect democratic link. Unsurprisingly, there is a large variety of types of commissions depending on its powers and, most importantly, its composition. For instance, the current English and the Scottish systems differ in that in the former lay members are in the minority, whereas in the latter they are in the majority (Paterson 2006). In Spain the Consejo General del Poder Judicial (CGPJ) is responsible for all promotions of judges below the Constitutional Court level. It contains twelve judges and eight legal professionals, chosen by Parliament on a party quota basis (Bell 2003).

A successful example of an appointments commission is the Israeli commission used to select Supreme Court judges, which consists of nine members (two members of parliament, two government ministers, two bar members and three Supreme Court judges). While Supreme Court judges are a minority, they represent the largest single block and are regarded as being able to easily influence the votes of the two bar members. This implies that in practice the commission is dominated by judicial actors. The Israeli Supreme Court is widely admired for its independence and contribution to the country's democratic development (Salzberger 2006).

\section{B Index of Intellectual Influence}

We now outline the method used in Section 3.3 to weight each citation by the intellectual influence of a representative article in the citing court. To construct this measure of intellectual influence we use the ranking method in Palacios-Huerta and Volij (2004) -henceforth PHV. We first identify the set of seven courts in our database:

$$
J=(\mathrm{HL}, \mathrm{CACiv}, \mathrm{CACrim}, \mathrm{QBD}, \mathrm{CHD}, \mathrm{FAM}, \mathrm{EAT})
$$

\footnotetext{
${ }^{29}$ In Japan lower level judges are appointed by the Supreme Court Secretariat but can be technically recalled by voters after 10 years. No judge has ever been recalled (O'Brien 2006).

${ }^{30}$ In some American states a 'merit commission' offers a list of three candidates to the governor, who has to choose one candidate from the list.
} 
We use the forty thousand cases in our database to construct the primitives of our problem. We construct a matrix of citations across courts, $C=\left(c_{i j}\right)_{(i j) \in J \times J}$, where $c_{i j}$ captures the total number of citations of cases in court $i$ by cases in court $j$ during our sample period. From $C$ we can easily calculate $c_{j}=\sum_{i \in J} c_{i j}$ (the total sum of citations made by cases in court $j$ ) and $D_{C}=\operatorname{diag}\left(c_{j}\right)_{j \in J}$ (the diagonal matrix with the sums of the courts' citations as its main diagonal). Lastly, we construct a vector $a \in\left(a_{i}\right)_{i \in J}$ (the number of cases in each court) and $A=\operatorname{diag}\left(a_{i}\right)_{i \in J}$.

Using these primitives, our objective is to construct a (normalised) cardinal ranking of the courts in $J$, that is, a vector of non-negative valuations $\left(v_{i}\right)_{i \in J}$. We will interpret $v_{j}$ as the intellectual influence of a representative article in court $j$. Intuitively, we would like a court $j$ to receive a higher valuation when it is cited both more often and by more influential courts. Of course, this creates a simultaneity problem. Following PHV, we derive $v$ as the solution to the following equation:

$$
C D_{C}^{-1} A v=A v
$$

PHV show that this ranking method is the unique method satisfying the properties of anonymity, invariance to citation intensity, weak homogeneity, weak consistency, and invariance to splitting of courts. We display the computed valuations in the first column of Table A4, together with the matrix of citations and the vector of number of cases. Lastly, we use the computed valuations to weight the citations received by a case. For example, if a case received two citations from CA Crim cases and one citation from a FAM case, we calculate the intellectual influence of this case as $.23=2 * .08+.07$.

Table A4

\begin{tabular}{l|ccccccccc}
\hline \hline & Valuation & \# of Cases & \multicolumn{7}{c}{ Citing Court } \\
\cline { 5 - 9 } Cited Court & & & HL & CA Civ & CA Crim & QBD & CHD & FAM & EAT \\
\hline HL & .64 & 769 & 95 & 556 & 187 & 556 & 230 & 41 & 102 \\
CA Civ & .11 & 8928 & 81 & 1873 & 19 & 1400 & 807 & 163 & 335 \\
CA Crim & .08 & 7606 & 27 & 16 & 2405 & 85 & 7 & 4 & 1 \\
QBD & .03 & 12977 & 23 & 405 & 70 & 1615 & 136 & 10 & 16 \\
CHD & .04 & 6128 & 14 & 271 & 6 & 169 & 907 & 8 & 8 \\
FAM & .07 & 1107 & 5 & 95 & 0 & 22 & 5 & 190 & 0 \\
EAT & .03 & 1921 & 4 & 58 & 1 & 8 & 2 & 0 & 410 \\
Total & 1 & 39436 & 249 & 3274 & 2688 & 3855 & 2094 & 416 & 872 \\
\hline
\end{tabular}




\section{A Brief History of The Constitutional Reform Act}

Consultation in the 1990s In 1994, in the wake of criticism from, e.g., Justice (a legal reform group) and The Law Society, the Lord Chancellor commissioned a Select Committee enquiry into judicial appointments, including consideration of a judicial appointments commission (JAC). Interim reports indicated that the Committee was split over the need for an independent JAC, with Labour members broadly in favour and Conservative members against. Consistent with this, at the 1995 Party Conference Labour publicly declared its support for a JAC. Significantly, the Judges' Council was strongly opposed, largely on the grounds that it would introduce politics into the process. In oral evidence to the Committee, the Lord Chief Justice (then the senior Head of Division) declared that he could not "imagine anything more horrific". The will of the judiciary quickly won out, with the Committee concluding in 1996 that there was no need for a large scale change.

Aborted consultation in 1997 Shortly after the election in May 1997, details of Labour's plans for a JAC were leaked to the press. The judiciary again seized the opportunity to voice its disapproval, with a senior Court of Appeal judge happily going on record to say that "Judges rightly would be concerned, until they see the White Paper, about the dangers of politicising the system". ${ }^{31}$ Although plans for a consultation exercise were formally announced a month later, the White Paper itself never emerged. In October 1997, the Lord Chancellor declared that the consultation had been shelved. This u-turn did not go unnoticed and prompted a sequence of questions in the House of Commons. In the summer of 1999, in the face of unprecedented criticism of the appointments system (fuelled by the rise of judicial review under the Human Rights Act 1998), the Lord Chancellor appointed Sir Leonard Peach to report on the operation of the appointments procedure. The terms of reference were strictly limited, however. Peach was to look at how appointments were made, not by whom, effectively ruling out consideration of a JAC. His report led to the creation of the Commission for Judicial Appointments, a (confusingly named) oversight body. Criticisms of the system rumbled on, however, heightened by negative reports by the CJA and the establishment of JACs in Scotland and Northern Ireland.

Reform Announced in 2003 In June 2003, the Prime Minister "took the legal world by surprise" (Malleson 2004) by simultaneously announcing that a JAC would be introduced and the

\footnotetext{
31 "Labour faces row over reforms to end elitism in the courts", The Times, May 271997.
} 
(1,000 year old) office of the Lord Chancellor abolished. This time there was no prior consultation, with senior judges, the Attorney General and the speaker of the House of Lords all unaware of the plans. The nature of the announcement prompted comments that the Government was trying to wrestle power from the judges. ${ }^{32}$ Although the Government did not consult on whether to introduce a JAC, it did solicit views on how the commission should operate. Broadly speaking, the Government was in favour of a recommending commission that left ultimate responsibility for appointments to a minister (citing the need to safeguard democratic accountability), while the judiciary was in favour of an appointing commission with a "promotions panel" consisting primarily of judges for the Court of Appeal and above (citing the need to safeguard judicial independence, as well as their superior knowledge of candidates). The passage of the Bill proved to be protracted. In February 2004 the Constitutional Affairs Committee reported that the Bill should be considered in draft, as the consultation had been "rushed". This did not happen but, at its second reading, the Bill was referred to a House of Lords Select Committee (a highly unusual step not used since the 1920's) as there had been no time for "pre-legislative scrutiny". The Bill, replete with a Concordat, finally received Royal Ascent in March 2005, nearly two years after its controversial announcement. The JAC was then created on April 32006 with the responsibility of selecting judges for appointment and promotion. The Commission consists of 15 members, including five judges, one tribunal member, one lay justice, two members of the legal profession (one barrister and one solicitor) and six lay people. The Chairman of the Commission is a lay person. All members are selected and appointed through open competition, with the exception of three judicial members who are selected by the Judges' Council. The key statutory responsibilities of the JAC include both to select candidates solely on merit, and to have regard to the need to encourage diversity. ${ }^{33}$ The JAC started the search to fill vacancies in the High Court in October 2006.

\footnotetext{
${ }^{32}$ See, for instance, Justice (who had called for a JAC since 1992) voicing their fears in The Times, "Is this a ruthless grab for power?" July 1 2003, and an article in The Economist questioning whether the Government was intent on "nobbling" the judiciary, "Blair's own goal" July 192003.

${ }^{33}$ See http://www.judicialappointments.gov.uk/about-jac/141.htm.
} 
Figure 1. The Structure of the Court System in England and Wales in 2005

The House of Lords (12)

\begin{tabular}{|c|}
\hline Elite: $94 \%$ \\
\hline
\end{tabular}

The Court of Appeal (37)

\begin{tabular}{|c|c|}
\hline Criminal Division & Civil Division \\
& Elite: $86 \%$ \\
\hline
\end{tabular}

The High Court

\begin{tabular}{|c||c|c|}
\hline Queen's Bench Division (72) & $\begin{array}{c}\text { Family } \\
\text { Division } \\
(19)\end{array}$ & $\begin{array}{c}\text { Chancery } \\
\text { Division } \\
(17) \\
\text { Elite: } 70 \%\end{array}$ \\
Elite: $76 \%$ \\
\hline
\end{tabular}

The Crown Court

County Courts

78 Regional Centres

Magistrates' courts 
Table 1. Exits from the High Court, by Elite Status

\begin{tabular}{|c|c|c|c|c|c|c|c|c|}
\hline \multirow{2}{*}{ State } & \multicolumn{2}{|c|}{ Full Sample } & \multicolumn{2}{|c|}{ Elite } & \multicolumn{2}{|c|}{ Non-Elite } & \multicolumn{2}{|c|}{ Difference } \\
\hline & No. & $\mathrm{Col} \%$ & No. & $\mathrm{Col} \%$ & No. & $\%$ & $\%$ & $p$-value \\
\hline Still Practicing & 108 & 39.27 & 74 & 37.95 & 34 & 42.50 & -4.55 & .485 \\
\hline Promoted & 85 & 30.91 & 76 & 38.97 & 9 & 11.25 & 27.72 & .000 \\
\hline Retired & 73 & 26.55 & 41 & 21.03 & 32 & 40.00 & -18.97 & .001 \\
\hline Died in Office & 7 & 2.55 & 3 & 1.54 & 4 & 5.00 & -3.46 & .099 \\
\hline Transfer to ECJ & 1 & 0.36 & 0 & 0 & 1 & 1.25 & -1.25 & .119 \\
\hline Resigned & 1 & 0.36 & 1 & .51 & 0 & 0 & -.51 & .523 \\
\hline Total & 275 & 100 & 195 & 100 & 80 & 100 & & \\
\hline
\end{tabular}

Panel B: Inflow Sample, Kaplan Meier Adjusted

\begin{tabular}{|c|c|c|c|c|}
\hline & $\begin{array}{l}\text { Full Sample } \\
\% \text { after } 14 \mathrm{yrs}\end{array}$ & $\begin{array}{c}\text { Elite } \\
\% \text { after } 14 \mathrm{yrs}\end{array}$ & $\begin{array}{l}\text { Non-Elite } \\
\% \text { after } 14 \mathrm{yrs}\end{array}$ & $\begin{array}{c}\text { Log Rank Test } \\
\text { p-value }\end{array}$ \\
\hline Promoted & 56.00 & 65.81 & 24.49 & .001 \\
\hline
\end{tabular}

Notes:

1. Unadjusted statistics based on the 275 judges serving between 3 June 1985 and 31 December 2005. Exit states at 31 December 2005.

2. Kaplan-Meier adjusted statistics based on the 240 judges appointed between 1 Jan 1980 and 31 December 2005. This inflow sample is a sub-set of the stock sample. Null hypothesis for log rank test is equality of survival functions. 
Table 2. Summary Statistics, by Elite Status

\section{Elite Status}

Elite

\section{Connectivity Status}

To Heads ${ }^{2}$

To Lord Chancellor

\section{Promotion Criteria}

Age at HC appointment (yrs)

Experience (yrs)

Match with needs of Court of Appeal

Vacancy same HC Division (\%)

Number of Cases in:

CHD

Family in FAM/QBD

Criminal law in QBD

Public law in QBD

Civil law in QBD/EAT

CA Crim

CA Civ

Total

Ability as Evidenced by Judgements

Reversed by a Head of Division

Affirmed by a Head of Division

'Stakes' of the Vacancy

Promotion Vacancy ${ }^{3}$

$\frac{\text { Full Sample }}{\text { Mean SD }}$

0.73

0.45

0.04

0.02

0.05

0.07

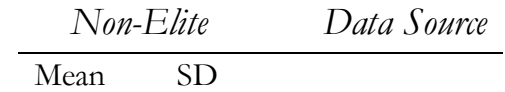

$0 \quad 0 \quad$ Annuals $^{1}$

10

$\begin{array}{ll}0.05 & 0.06\end{array}$

$\begin{array}{ll}0.02 & 0.07\end{array}$

$0.02 \quad 0.04$

$0.01 \quad 0.05$

Annuals
53.1

7.10

3.84

3.52

52.54

5.54
7.02

\subsection{3}

3.31

0.42

0.42

0.40

0.42

$12.38 \quad 34.01$

$12.15 \quad 33.67$

$4.77 \quad 10.83$

$3.74 \quad 7.68$

6.75

14.03

14.93

25.85

2.98

21.67

43.36

8.70

69.65

5.20

11.59

$3.55 \quad 7.52$

$7.49 \quad 15.30$

$\begin{array}{ll}16.86 & 23.25\end{array}$

$20.51 \quad 35.59$

$3.27 \quad 9.66$

$69.36 \quad 68.85$

$0.06 \quad 0.15$

0.11

0.26

0.06

0.12

0.14

0.29

0.06

0.07

0.17

0.20

0.40

0.39

MoJ

MoJ

Westlaw

$39.94 \quad 56.99$

$2.20 \quad 5.31$

$76.30 \quad 71.75$

0.42

0.41

0.43

0.41

MoJ
0.40

Notes: Means calculated for the 510 alternatives in the estimation sub-sample (see Section 3).

1. Data on education (school and university) from Who's Who. Data on occupational location from the Law List, the Bar List, Butterworth's, Haver's Companion to the Bar, Chambers and Partners, and Hazell's Guide.

2. Connectivity status is measured along four dimensions: same school, same university (same college if Oxbridge), same chambers and same Gentleman's Club (the latter is obtained from Who's Who). Both variables are normalised to [0,1]. For 'Connectivity to Heads', the maximum score (i.e. 1) would be achieved if an alternative was connected to all four Heads of Division along all four dimensions.

3. 'Promotion Vacancy' measures whether the vacancy in the Court of Appeal (for which the High Court judge is a candidate) has been generated as a result of a promotion of a Court of Appeal judge. It takes value 1 when this is the case and value 0 when the vacancy has been generated as a result of the retirement of a Court of Appeal judge or the statutory creation of a new post. For the few occasions where there is more than one unfilled vacancy, 'Promotion Vacancy' measures the proportion of vacancies generated by promotions. 


\section{Table 3. Discrete Choice Models}

\section{Dependent Variable: 1 if judge $j$ is chosen by promotion committee $n, 0$ otherwise}

Alternative Set: committee $n$ 's choice plus 5 judges selected at random from the set of contemporaneously serving HC judges

\begin{tabular}{|c|c|c|c|c|c|c|c|c|c|c|c|c|}
\hline \multirow{2}{*}{ Explanatory Variables } & \multicolumn{3}{|c|}{$\begin{array}{c}1 \\
\text { Baseline }\end{array}$} & \multicolumn{3}{|c|}{$\begin{array}{c}2 \\
\text { Plus Promotion Criteria }\end{array}$} & \multicolumn{4}{|c|}{$\begin{array}{c}3 \\
\text { Plus Connectivity }\end{array}$} & \multicolumn{2}{|c|}{$\begin{array}{c}4 \\
\text { Plus Prom. Vacancy }\end{array}$} \\
\hline & Coeff & RobSE & $\exp (b)$ & Coeff & RobSE & $\exp (b)$ & Coeff & & RobSE & $\exp (b)$ & Coeff & RobSE \\
\hline Elite & $1.349^{* * *}$ & 0.386 & 3. 85 & $0.887^{* *}$ & 0.453 & 2.42 & 1.007 & ** & 0.430 & 2.74 & 1.381 & 0.693 \\
\hline Elite*Promotion Vacancy & & & & & & & & & & & -0.935 & 1.151 \\
\hline Connectivity to Heads & & & & & & & -6.072 & ** & 2.571 & & -6.457 & 2.675 \\
\hline Connectivity to Lord Chancellor & & & & & & & 1.754 & & 2.516 & & 1.929 & 2.570 \\
\hline$J-1$ Alternative Constants? & & No & & & Yes & & & & Yes & & Yes & \\
\hline \multicolumn{13}{|l|}{ Promotion Criteria? } \\
\hline Age at HC appoint. (quadratic) & & No & & & Yes & & & & Yes & & Yes & \\
\hline Experience in HC (quadratic) & & No & & & Yes & & & & Yes & & Yes & \\
\hline Vacancy same HC division & & No & & & Yes & & & & Yes & & Yes & \\
\hline Case-based legal specialism & & No & & & Yes & & & & Yes & & Yes & \\
\hline Affirmed by a Head & & No & & & Yes & & & & Yes & & Yes & \\
\hline Reversed by a Head & & No & & & Yes & & & & Yes & & Yes & \\
\hline No. of Committees (N) & & 85 & & & 85 & & & & 85 & & 85 & \\
\hline No. of Observations (NJ) & & 510 & & & 510 & & & & 510 & & 510 & \\
\hline Log Likelihood (ßhat) & & 143.65 & & & -63.59 & & & & 62.03 & & -61.79 & \\
\hline Pseudo $\mathrm{R}^{2}=1-(\mathrm{LL}(\beta$ hat $) / \mathrm{LL}(0))$ & & 0.057 & & & 0.583 & & & & .593 & & 0.594 & \\
\hline
\end{tabular}

Notes: Random draws from a set excluding judges with less than two years experience. Unreported coefficients can be found in the Appendix in Table A2.

The variables 'Promotion Vacancy', 'Connectivity to Head's and 'Connectivity to Lord Chancellor' are described in the notes to Table 2. The variable

'Promotion Vacancy' cannot be included alone in this specification because it does not vary across alternatives (candidates for promotion). 


\section{Table 4. Discrete Choice Models: Decomposition of the Elite Differential}

\begin{tabular}{|c|c|c|c|c|c|c|}
\hline \multicolumn{7}{|c|}{ Dependent Variable: 1 if judge $j$ is chosen by promotion committee $n, 0$ otherwise } \\
\hline \multicolumn{7}{|c|}{ Alternative Set: committee $n$ 's choice plus 5 judges selected at random from the set of HC judges } \\
\hline \multirow[t]{2}{*}{ Explanatory Variables (no. of judges) } & \multicolumn{3}{|c|}{$\begin{array}{c}1 \\
\text { Baseline }\end{array}$} & \multirow{2}{*}{\multicolumn{3}{|c|}{ 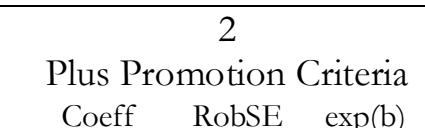 }} \\
\hline & Coeff & RobSE & $\exp (b)$ & & & \\
\hline \multicolumn{7}{|l|}{ Panel $A^{1}$} \\
\hline \multicolumn{7}{|l|}{ Panel B } \\
\hline Private-Oxbridge-Top Ranking Chambers (57) & $0.983^{* *}$ & 0.462 & 2.67 & 0.559 & 0.537 & 1.75 \\
\hline Private-Other (128) & $0.794^{*}$ & 0.412 & 2.21 & 0.832 & 0.621 & 2.30 \\
\hline State-Oxbridge-Top Ranking Chambers (10) & $1.672^{* * *}$ & 0.644 & 5.33 & 1.072 & 1.301 & 2.92 \\
\hline State-Other (42) & \multicolumn{3}{|c|}{ Omitted } & \multicolumn{3}{|c|}{ Omitted } \\
\hline Promoted-Circuit (38) & $-1.870^{*}$ & 0.971 & 0.15 & -0.756 & 0.999 & 0.47 \\
\hline$J$-1 Alternative Constants? & \multicolumn{3}{|c|}{ No } & \multicolumn{3}{|c|}{ Yes } \\
\hline Promotion Criteria? & \multicolumn{3}{|c|}{ No } & \multicolumn{3}{|c|}{ Yes } \\
\hline No. of Committees $(\mathrm{N})$ & \multicolumn{3}{|c|}{85} & \multicolumn{3}{|c|}{85} \\
\hline No. of Observations (NJ) & \multicolumn{3}{|c|}{510} & \multicolumn{3}{|c|}{510} \\
\hline$F$-test for jointly significant dummies, $p$-value & \multicolumn{3}{|c|}{0.002} & \multicolumn{3}{|c|}{0.246} \\
\hline Log Likelihood ( $\beta$ hat) & \multicolumn{3}{|c|}{-139.98} & \multicolumn{3}{|c|}{-63.25} \\
\hline Pseudo $\mathrm{R}^{2}=1-(\mathrm{LL}(\beta$ hat $) / \mathrm{LL}(0))$ & \multicolumn{3}{|c|}{0.081} & \multicolumn{3}{|c|}{0.585} \\
\hline \multicolumn{7}{|l|}{ Panel C } \\
\hline Private-Oxbridge-Top Ranking Chambers (57) & \multicolumn{3}{|c|}{ Omitted } & \multicolumn{3}{|c|}{ Omitted } \\
\hline Private-Other (128) & -0.190 & 0.272 & 0.83 & 0.274 & 0.424 & 1.32 \\
\hline State-Oxbridge-Top Ranking Chambers (10) & 0.689 & 0.557 & 1.99 & 0.513 & 1.154 & 1.67 \\
\hline State-Other (42) & $-0.983^{* *}$ & 0.462 & 0.37 & -0.559 & 0.537 & 0.57 \\
\hline Promoted-Circuit (38) & $-2.853^{* * *}$ & 0.915 & 0.06 & -1.315 & 0.861 & 0.27 \\
\hline
\end{tabular}

Notes: Panel A reports the coefficients from Columns 1 and 2 in Table 3. The 'Route to the Bench' categories listed in Panel B are defined in Section 2.3. Promotion Criteria include all variables introduced in Column 2 of Table 3. The specification in Panel C is identical to that in Panel B except that a different 'Route to the Bench' is used as an excluded category. 
Table 5. Post Promotion Performance in the Court of Appeal (Civil Division)

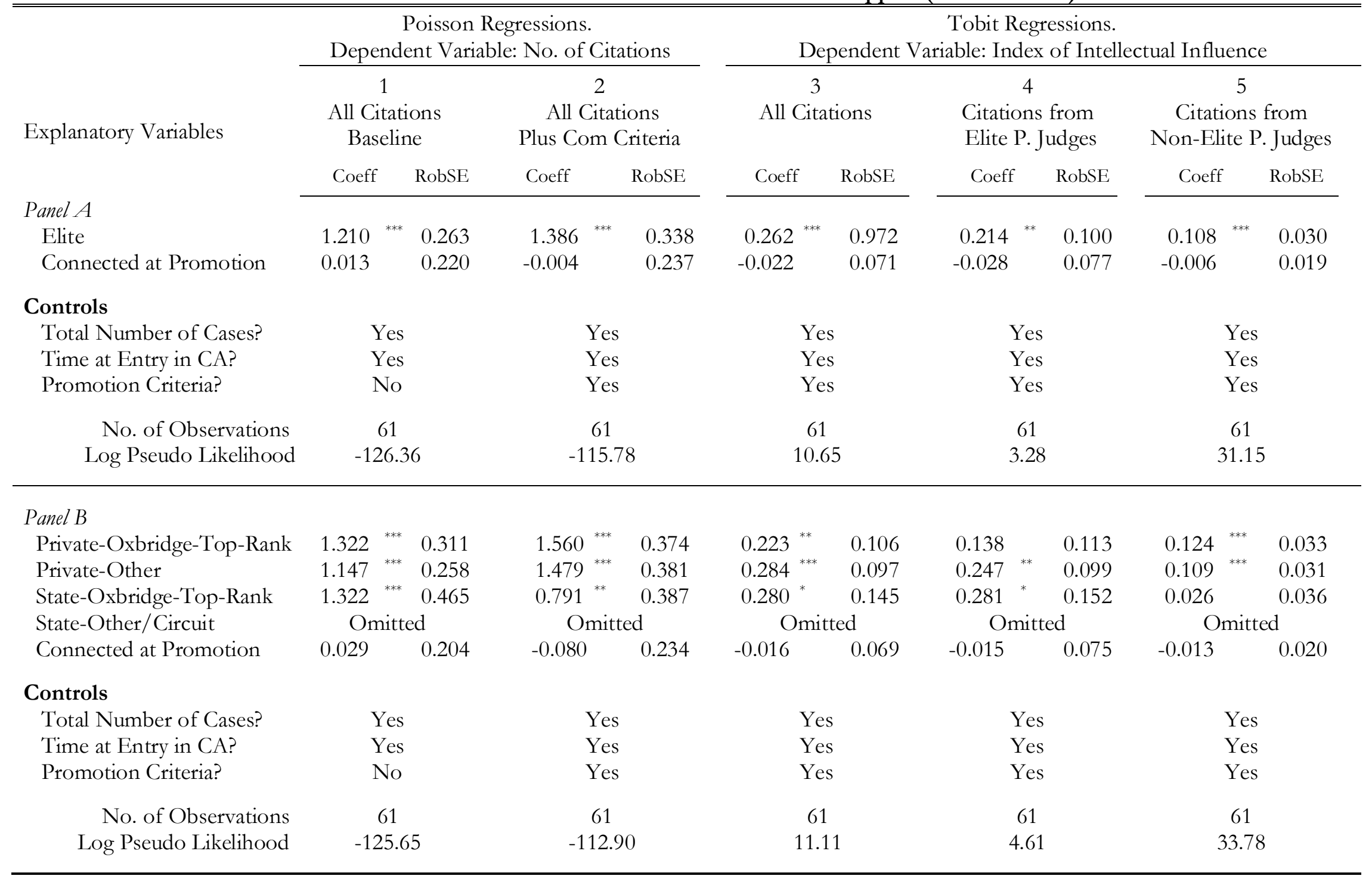

Notes: Promotion Criteria include all variables introduced in Column 2 of Table 3. A 'mean response' value in the Poisson regressions can be calculated by multiplying the mean of the dependent variable (3.63) by the estimated coefficient. 
Table 6. Discrete Choice Models, with Time Period Interactions

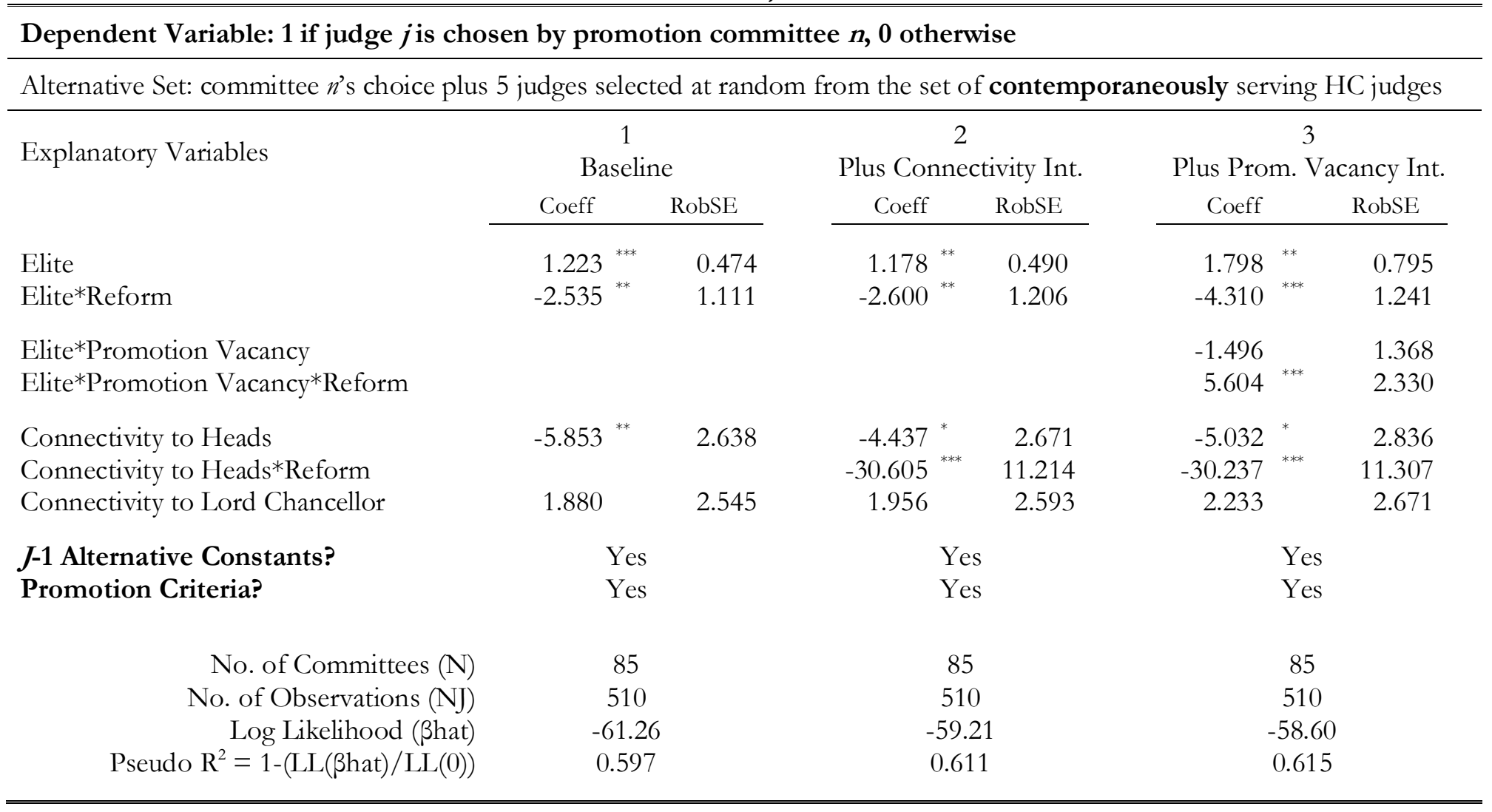

Notes: Random draws from a set excluding judges with less than two years experience. Unreported coefficients can be found in the Appendix in Table A5. The variables 'Reform', 'Promotion Vacancy' and cannot be included alone in this specification because they do not vary across alternatives. Promotion Criteria include all variables introduced in Column 2 of Table 3. 
Table A1. Classification of London Sets by Law Directory Ranking

\begin{tabular}{|c|c|c|c|}
\hline Specialism & Ranked? & Sets & \\
\hline \multirow[b]{2}{*}{ Civil } & $\begin{array}{l}\text { Lawyer } \\
\text { Top } 30\end{array}$ & $\begin{array}{l}\text { Brick Court ( } 7 / 8 \text { Essex Street), Essex Court (24 Lincolns Inn) } \\
1 \text { Essex Court (Temple), Fountain Court (Temple), } 20 \text { Essex Street, } \\
7 \text { King's Bench Walk (Temple), Keating Chambers (15 Essex Street) } \\
4 \text { Pump Court (Temple), Littleton Chambers (Temple) }\end{array}$ & 9 \\
\hline & $\begin{array}{l}\text { C\& P } \\
\text { Listed }\end{array}$ & $\begin{array}{l}1 \text { Brick Court (Temple), Cloisters (1 Pump Court, Temple) } \\
2 \text { Crown Office Row (Temple), Devereux Chambers (Devereux Court) } \\
2 \text { Essex Court, } 3 \text { Essex Court, } 4 \text { Essex Court (Temple),10 Essex Street, } \\
\text { Falcon Chambers (Temple), Farrar's Building (Temple) } \\
\text { Francis Taylor Building (Temple), } 3 \text { Gray's Inn Place (Gray's Inn) } \\
1 \text { Harcourt Buildings (Temple), } 12 \text { King's Bench Walk (Temple) } \\
\text { Lamb Building (Temple), Monckton Chambers (Gray's Inn) } \\
\text { New Court, } 2 \text { New Square, } 5 \text { New Square, } 7 \text { New Square, } 8 \text { New Square } \\
\text { (Lincoln's Inn), } 1 \text { Paper Buildings (Temple), } 6 \text { Pump Court (Temple), } \\
5 \text { Raymond Buildings (Gray's Inn), } 11 \text { South Square (Gray's Inn) } \\
2 \text { Temple Gardens (Temple) }\end{array}$ & $\begin{array}{l}2 \\
6\end{array}$ \\
\hline \multirow[b]{2}{*}{ Public } & $\begin{array}{l}\text { Lawyer } \\
\text { Top } 30\end{array}$ & $\begin{array}{l}39 \text { Essex Street, } 1 \text { Crown Office Row (Temple), 2-3 Gray's Inn Square, } \\
\text { 4-5 Gray's Inn Square (Gray's Inn), Matrix Chambers (Gray's Inn) }\end{array}$ & 5 \\
\hline & $\begin{array}{l}\text { C\& P } \\
\text { Listed }\end{array}$ & $\begin{array}{l}2 \text { Garden Court (Temple), } 4 \text { Breams Buildings, } 2 \text { Harcourt Buildings } \\
\text { (Temple), } 11 \text { King's Bench Walk (Temple), } 2 \text { Paper Buildings (Temple) } \\
\text { Took Court Chambers (14 Took's Court) }\end{array}$ & 6 \\
\hline \multirow[b]{2}{*}{ Chancery } & $\begin{array}{l}\text { Lawyer } \\
\text { Top } 30^{1}\end{array}$ & $\begin{array}{l}9 \text { Old Square, } 13 \text { Old Square (Lincoln’s Inn) } \\
7 \text { Stone Buildings (Lincoln's Inn) }\end{array}$ & 3 \\
\hline & $\begin{array}{l}\text { C\& P } \\
\text { Listed }\end{array}$ & $\begin{array}{l}\text { Erskine Chambers (Lincoln's Inn), Gray's Inn Chambers (Gray's Inn) } \\
1 \text { New Square, } 3 \text { New Square (Lincoln's Inn), } 11 \text { Old Square (Lincoln's Inn), } \\
4 \text { Stone Buildings, } 5 \text { Stone Buildings (Lincoln's Inn) }\end{array}$ & 7 \\
\hline Crime & $\begin{array}{l}\text { C\& P } \\
\text { Listed }\end{array}$ & $\begin{array}{l}9 \text { Bedford Row, } 36 \text { Bedford Row, } \\
4 \text { Brick Court (Temple), } 23 \text { Essex Street } \\
1 \text { Gray's Inn Square (Gray's Inn), } 1 \text { Hare Court, } 2 \text { Hare Court (Temple) } \\
5 \text { Paper Buildings (Temple) } \\
4 \text { King's Bench Walk, } 5 \text { King's Bench Walk, } 6 \text { King's Bench Walk (Tempe) }\end{array}$ & 10 \\
\hline Family & $\begin{array}{l}\text { C\& P } \\
\text { Listed }\end{array}$ & $\begin{array}{l}2 \text { Dr Johnson's Building (Temple) } \\
1 \text { King's Bench Walk (Temple), } 1 \text { Mitre Court Buildings (Temple) } \\
4 \text { Paper Buildings (Temple), Queen Elizabeth Building (Temple) }\end{array}$ & 6 \\
\hline Not C\& P & Listed & $\begin{array}{l}\text { Dr Johnson's Building (Temple), Goldsmith Building (Temple) } \\
3 \text { Paper Buildings (Temple), } 2 \text { Pump Court (Temple) } \\
\text { Chambers of Peter Rook (Lion Court), } 11 \text { New Court (Lincoln's Inn) } \\
5 \text { Essex Court (Temple) }\end{array}$ & 7 \\
\hline
\end{tabular}

Notes: Lawyer Top 30 Ranking in 2005 (used to classify sets as a 'leading London set); C\&P Listings in (at least one of) 1990 , 1994/5, 1999/2000 and 2003/4. 
Table A2. Unreported Coefficients from Discrete Choice Model in Table 3

\begin{tabular}{|c|c|c|c|c|}
\hline \multicolumn{5}{|c|}{ Dependent Variable: 1 if judge $j$ is chosen by promotion committee $n, 0$ otherwise } \\
\hline \multicolumn{5}{|c|}{$\begin{array}{l}\text { Alternative Set: committee } n \text { 's choice plus } 5 \text { judges selected at random from the set of } \\
\text { contemporaneously serving HC judges }\end{array}$} \\
\hline \multirow{2}{*}{$\begin{array}{l}\text { Explanatory Variables } \\
\text { (all calculated up to tournament date) }\end{array}$} & \multicolumn{2}{|c|}{$\begin{array}{c}3 \\
\text { Plus Connectivity }\end{array}$} & \multicolumn{2}{|c|}{$\begin{array}{c}4 \\
\text { Plus Prom. Vacancy }\end{array}$} \\
\hline & Coeff & Robust SE & Coeff & Robust SE \\
\hline \multicolumn{5}{|l|}{ Age } \\
\hline Age at High Court Entry (yrs) & 4.972 & *** 1.692 & $5.027^{* *}$ & 1.684 \\
\hline Quadratic Term & -0.051 & *** 0.165 & $-0.051 * *$ & 0.016 \\
\hline \multicolumn{5}{|l|}{ Experience } \\
\hline Experience in $\mathrm{HC}$ (yrs) & 1.357 & * 0.710 & 1.313 & 0.738 \\
\hline Quadratic Term & -0.094 & ** 0.038 & $-0.092 *$ & 0.039 \\
\hline \multicolumn{5}{|l|}{ Appeal Based Measures } \\
\hline Reversed by a Head of Division (\%) & -3.309 & 2.345 & -3.280 & 2.377 \\
\hline Affirmed by a Head of Division ( $\%)$ & -0.487 & 1.107 & -0.451 & 1.124 \\
\hline \multicolumn{5}{|l|}{ Case Based Legal Specialism } \\
\hline Vacancy Same HC Division (\%) & 1.555 & *** 0.022 & $1.590 * *$ & 0.540 \\
\hline \# cases in CHD (1) & -0.035 & 0.025 & -0.035 & 0.025 \\
\hline \# family law cases in FAM/QBD (2) & -0.070 & * 0.042 & -0.071 & 0.042 \\
\hline \# criminal law cases in QBD (3) & -0.056 & 0.052 & -0.058 & 0.054 \\
\hline \# public law cases in QBD (4) & -0.028 & 0.029 & -0.029 & 0.030 \\
\hline \# civil law cases in QBD/EAT (5) & -0.029 & 0.024 & 0.030 & 0.024 \\
\hline \# cases in CA Crim (6) & -0.057 & ** 0.022 & $-0.058^{*}$ & 0.022 \\
\hline$\#$ cases in CA Civ $(7)$ & \multicolumn{2}{|c|}{ Omitted } & \multicolumn{2}{|c|}{ Omitted } \\
\hline Total \# cases (sum 1-7) & 0.064 & *** 0.022 & $0.065^{* *}$ & 0.022 \\
\hline$F$-test Case Specialism Contols ( $p$-value) & & 0.002 & & 02 \\
\hline No. of Committees & & 85 & & 5 \\
\hline No. of Observations & & 510 & & 10 \\
\hline Log Likelihood ( $\beta$ hat) & & -62.03 & & .79 \\
\hline Pseudo $\mathrm{R}^{2}=1-(\mathrm{LL}(\beta$ hat $) / \mathrm{LL}(0))$ & & 0.593 & & 94 \\
\hline
\end{tabular}


Table A3. Case Allocation in the Court of Appeal (Civil Division)

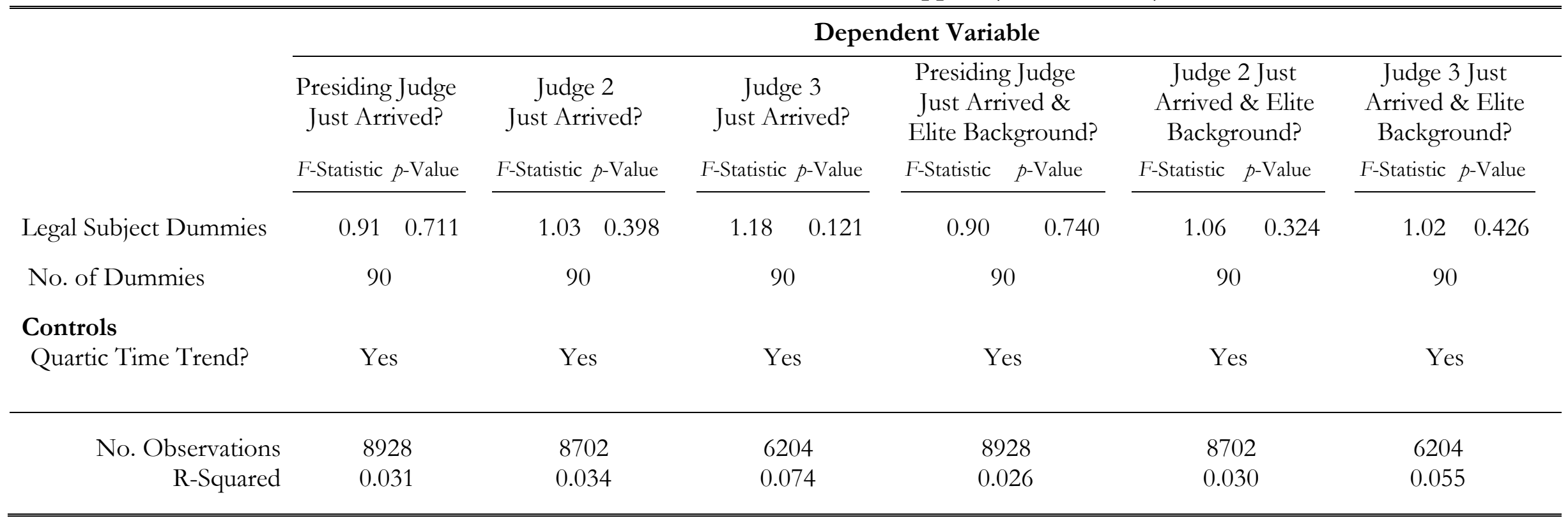

Notes: Regressions run on the 8928 cases from the Court of Appeal (Civil Division) held on Westlaw. Each regression includes 90 legal subject dummies.

The F-statistic and p-Values refer to a test of the joint significance of these 90 legal subject dummies. 
Table A5. Unreported Coefficients from Discrete Choice Model in Table 6

Dependent Variable: 1 if judge $j$ is chosen by promotion committee $n, 0$ otherwise

Alternative Set: committee $n$ 's choice plus 5 judges selected at random from the set of contemporaneously serving HC judges

Explanatory Variables

1

Baseline

Coeff RobSE

Age:

Age at High Court Entry (yrs)

Quadratic Term

\section{Experience}

Experience in HC (yrs)

Quadratic Term

\section{Appeal Based Measures:}

Reversed by a Head of Div (\%)

Affirmed by a Head of Div (\%)

\section{Case Based Legal Specialism}

Vacancy Same HC Division (\%)

\# cases in CHD (1)

\# family law cases in FAM/QBD (2)

\# criminal law cases in QBD (3)

\# public law cases in QBD (4)

\# civil law cases in QBD/EAT (5)

\# cases in CA Crim (6)

\# cases in CA Civ (7)

Total \# cases (sum 1-7)
$5.083^{* * *} \quad 1.716$

$-0.051^{* * *} 0.167$

$\begin{aligned} 5.172^{* * *} & -0.053^{* * *}\end{aligned}$

1.818

0.177

$5.246^{* * *} 1.802$

$-0.053^{* * *} 0.177$

$$
\begin{array}{rr}
1.442^{* *} \quad 0.720 \\
-0.099^{* *} & 0.038
\end{array}
$$

$\begin{array}{rr}1.340^{*} & 0.725 \\ -0.094^{* *} & 0.039\end{array}$

1.276

$-0.093^{* *} 0.041$

$-2.931$

2.319

$-3.371$

2.357

$-3.285$

2.355

$-0.767$

1.083

$-0.563$

1.007

$0.597-1.008$

$\begin{array}{lr}1.547^{* * *} & 0.540 \\ -0.038 & 0.025 \\ -0.073^{*} & 0.041 \\ -0.061 & 0.053 \\ -0.028 & 0.029 \\ -0.029 & 0.024 \\ -0.060^{* * *} & 0.022 \\ { }^{*} \text { Omitted } \\ 0.066^{* * *} & 0.022\end{array}$

\begin{tabular}{cc}
$1.606^{* * *}$ & 0.533 \\
$-0.042^{*}$ & 0.024 \\
$-0.080^{* *}$ & 0.039 \\
-0.067 & 0.057 \\
-0.026 & 0.029 \\
0.034 & 0.022 \\
$-0.058^{* *}$ & 0.022 \\
\multicolumn{2}{c}{ Omitted } \\
0.075
\end{tabular}

$1.636^{* * *} 0.540$

$-0.043 * 0.024$

$-0.081^{* *} 0.039$

$\begin{array}{ll}-0.066 & 0.607\end{array}$

$\begin{array}{ll}-0.027 & 0.303\end{array}$

$-0.035 \quad 0.023$

$-0.070^{* * *} 0.020$

Omitted

$0.075^{* * *} 0.021$

$0.076^{* * *} 0.022$
$F$-test Case Specialism Ctrls ( $p$-value)

0.002

No. of Committees

No. of Observations

Log Likelihood (Bhat)

Pseudo $\mathrm{R}^{2}=1-(\mathrm{LL}(\beta$ hat $) / \mathrm{LL}(0))$

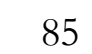

510

$-61.26$

0.597
0.001

85

510

$-59.21$

0.611
0.002

85

510

$-58.61$

0.615 